\title{
A Comparative Analysis of the Effects of the African Continental Free Trade Agreement on the Economic Impacts of COVID-19 in North and Southern Africa
}

\author{
Pousseni Bakouan ${ }^{1+}$, Issaka Dialga ${ }^{2,3}$, and Patrice Rélouendé Zidouemba ${ }^{4}$ \\ ${ }^{1}$ University Norbert Zongo, Burkina Faso \\ ${ }^{2}$ University Thomas Sankara, Burkina Faso \\ ${ }^{3}$ University of Nantes, France \\ ${ }^{4}$ University Nazi Boni, Burkina Faso
}

\begin{abstract}
COVID-19 has forced many governments to take emergency health measures which are undermining productive capacities and disrupting global supply chains. Southern and Northern Africa have been heavily impacted by such measures. According to UNCTAD statistics (2021), the average annual growth rate of exports in Northern and Southern Africa fell by $27.61 \%$ and 6.96\%, respectively in 2020. Yet, the effective operationalization of the African Continental Free Trade Agreement (AfCFTA) could have limited some of the pandemic's economic impacts. Using a computable general equilibrium model, this paper first analyzes the pandemic's economic impact and then assesses the ability of the AfCFTA to mitigate the economic impacts of COVID-19. The simulation results show that the AfCFTA would mitigate the economic impact in Southern and Northern Africa. It reduces the decline in intra-regional exports by 7.87 percentage points in 2021. The study emphasizes the need to remove non-tariff barriers to amplify potential positive effects.
\end{abstract}

Keywords: COVID-19, AfCFTA, CGE model, Southern Africa, North Africa

JEL Classifications: C68, F13, F15, I18

Received 6 September 2021, Revised 21 December 2021, Accepted 23 December 2021

\section{Introduction}

As of June 2, 2021, the World Health Organization (WHO) ${ }^{1)}$ statistics counted 3,557,586 deaths due to the coronavirus disease (COVID-19) out of 170,812,850 confirmed cases and $1,581,509,628$ doses of vaccine administered. Africa recorded its first COVID-19 case on February 14, 2020, in Egypt. Since then, the virus has spread rapidly across the continent, totaling

+Corresponding Author: Pousseni Bakouan

Ph.D. Candidate, Applied Economics, University Norbert Zongo, Koudougou, Burkina Faso.

Email: bakouan7pousseni@gmail.com

Co-Author: Issaka Dialga

Ph.D., Department of Economics, University Thomas Sankara, Ouagadougou, Burkina Faso / University of Nantes, France.

Email: issaka.dialga@univ-nantes.fr

Co-Author: Patrice Rélouendé Zidouemba

Ph.D., Maitre de conférences agrégé, University Nazi Boni, Bobo-Dioulasso, Burkina Faso.

Email: patrice.zidouemba@gmail.com 
4,898,938 confirmed cases. Cumulative cases in Africa represent $3 \%$ of the global total and deaths represent $4 \%$. From a regional perspective, Southern Africa accounts for 37\% of confirmed cases and is the continent's first most affected area. This is followed by North Africa $(30.23 \%)$, East Africa (18.40\%), West Africa (9.69\%), and Central Africa (4.17\%).

COVID-19 has forced governments to take emergency health measures, including the closure and strengthening of border controls, export restrictions as remedial measures, lockdowns, and temporary cessation of economic activities to contain the virus (Giammetti et al., 2020). The restrictive measures on exports across Africa represent $11.71 \%$ of the measures adopted at the world level (Thiam et al., 2021). These measures affected productive economic units, the labor market, and aggregate demand due to the interdependence of economic agents and sectors. The pandemic has caused a drastic reduction in the aggregate supply of goods and services due to lower productivity and temporary suspensions of business activities. The fall in aggregate demand is linked to reductions in the workforce, particularly through layoffs, but also to losses in income, which affect household consumption patterns and business investment decisions. High investment and raw material supply costs have affected the price levels of food goods (Agyei et al., 2021; Baldwin \& Mauro, 2020; Baldwin \& Tomiura, 2020; CEDEAO, 2020; Djiofack Zebaze et al., 2020; Rosenberg et al., 2021).

Thus, the health crisis has had a strong negative impact on global economic growth. For example, Fernandes (2020) shows that on average each additional month of crisis costs $2.5-3 \%$ of global Gross Domestic Product (GDP). Similarly, the Banque Mondiale (2020) projected a decline in economic growth ranging from $-2.1 \%$ to $-5.1 \%$ in 2020 in sub-Saharan Africa compared to the economic growth of $+2.4 \%$ in 2019 . Real GDP fell for the first time in more than 30 years by $2.6 \%$ in 2020 , and the contraction in GDP per capita was even more marked at $4.7 \%$ (Coguic \& Osman, 2021). The FMI (2020) shows that resource-rich and tourism-dependent countries are the most affected in sub-Saharan Africa. At the sub-regional level, NUCEA (2020) projects a decline in economic growth in North Africa to $-1.8 \%$ in 2020 while the loss of fulltime equivalent jobs could reach 5 million in 2020. The 50\% drop in oil prices and containment will lead to a drop of $4.5 \%$ to $5.8 \%$ in Algeria's GDP in 2020. Morocco and Tunisia, whose economies have been hit by the fall in tourism and related demand from the European Union, would experience GDP decline by $3.7 \%$ and $5 \%$, respectively.

Simultaneously, the response to COVID-19 has particularly affected trade and tourism activities due to their often-transnational nature (Tröster \& Küblböck, 2020). Increased trade costs obstruct the supply channel for goods and constitute a key element in the transmission of COVID-19 effects. Debuquet et al. (2020) and UNECA (2020) reported significant harassment on African trade corridors that cause bottlenecks, delays in goods deliveries, and additional costs in the transport sector. Restrictive measures have contributed to increased transport time due to sanitary control

1) https://who.maps.arcgis.com/apps/dashboards/0c9b3a8b68d0437a8cf28581e9c063a9 
requirements (Bouët \& Laborde, 2020). These institutional distortions have sometimes led to corrupt behavior on transnational corridors. Among these measures, the introduction of curfews has complicated night-time freight, where, because of their characteristics, fresh and perishable products are usually transported then.

Additionally, the pandemic has caused an unprecedented collapse of trade in goods and services in Africa due to their high external integration, particularly their dependence on global demand. WTO (2020) estimates indicate that the pandemic's economic shock leads to a net decline in world trade of $13-32 \%$ in 2020 due to uncertainty. In addition, UNCTAD statistics (2021) show a contraction in African exports in 2020 of $2.8 \%$ in the first quarter, $21.8 \%$ in the second, and $13.65 \%$ in the third compared to the same periods in 2019. Along with exports, African imports recorded declines of $1.5 \%, 16.8 \%$, and $8.47 \%$ in the first, second, and third quarters of 2020 , respectively, compared to 2019.

Respectively, North and Southern Africa faced a decline in export of $27.61 \%$ and $7 \%$ in 2020 , whereas in 2018 , their exports grew by $19.18 \%$ and $6 \%$, respectively. The subregions suffered significant losses due to two amplifying effects. First, intra-regional trade in North Africa and Southern Africa is weak. For example, in 2019, intra-area exports accounted for $5.24 \%$ of total exports in North Africa and $13.51 \%$ in Southern Africa. This poor regional trade integration is partly due to complex tax and customs systems and low transport infrastructure coverage (PNUD, 2017). Second, countries in both subregions are highly dependent on the export of natural (mineral) resources and tourism, which further exposes them to the negative effects of the pandemic. That leads Banque Mondiale (2020) to argue that trade-restrictive measures have significant economic consequences for African countries.

Trade liberalization in goods and services is expected to be integral in mitigating the economic impact of COVID-19. The elimination of intra-African trade barriers would allow firms to have cheaper access to inputs needed for production. The World Bank (2020) and Zidouemba and Jallab (2021) point out that the African Continental Free Trade Agreement (AfCFTA) increases incomes, employment, and exports of industrial and intermediate goods, which is a catalyst for Africa's structural economic transformation. From this perspective, African economies must accelerate the implementation of the AfCFTA $^{2}$ ) and trade liberalization reforms (WTO, 2020). For the WTO, the AfCFTA represents a real trade lever for African countries faced with falling external trade flows. As such, its operationalization when considering COVID-19 can help facilitate the supply of essential goods. The AfCFTA could mitigate Africa's negative economic effects.

As such, it seems clear that COVID-19 and its restrictive measures are causing economic

2) The AfCFTA, the world's largest free trade area, was launched at the 10th Extraordinary Assembly of Heads of State and Government of the African Union (AU) in March 2018 in Kigali, Rwanda. It now has 54 signatory countries and 36 countries have deposited their instruments of ratification. The AfCFTA was officially launched in January 2021. For the CEA (2017), it aims to further boost intra-African trade and investment, stimulate industrialization and increase employment opportunities, and improve the global competitiveness of African industries. 
recessions in Africa. However, among the alternative solutions to enable these economies to be resilient, one can assume that the effects of the implementation of the AfCFTA might be relevant to mitigate the impacts of the crisis. Thus, the main objective of this paper is to assess the mitigating effects of the AfCFTA on the negative economic impacts of COVID-19. To do so, the paper focuses on the following macroeconomic variables: imports, exports, consumption, and the demand for production factors. It also assesses the magnitude of these effects at the sectoral level: industry, services, and agriculture using a dynamic computable general equilibrium model.

The remainder of the article is organized as follows: a brief review of the recent literature in Section 2, the methodology in Section 3, the results in Section 4, and the conclusion and main implications in Section 5.

\section{Literature Review}

COVID-19 has caused an unprecedented supply and demand shock to the global economy. Governments, to thwart the virus' spread, preserve the health of their populations, and protect their livelihoods, took unilateral measures ranging from restricting travel across land borders to confining populations (BanqueMondiale, 2020; WHO, 2020). Given the virus' rapid spread and its almost unprecedented nature, most containment measures in the early stages were taken unilaterally because of the length of time it often took to make concerted decisions. The reactions of public authorities through measures to contain the virus led to a slowdown in economic activity.

Theoretical literature shows that unilateral trade restrictions have negative impacts on both the preservation of human health and economic activities. According to Aazi et al. (2020), these decisions have had repercussions on the supply of goods and services through the decrease in production of economic units, but also on demand through the decrease in consumption and investment due to economic uncertainty. Thiam et al. (2021) argue that export restrictions in attempting to control COVID-19 have seriously hampered the supply of medical goods to health centers and equate the health crisis with a return to consensual protectionism with export restrictions on medical goods to address the national health emergency. Moreover, Bayham and Fenichel (2020) show that school closures caused a shortage in health centers as health workers were forced to attend to their children at home.

Trade restrictions have negative impacts on economies and people's welfare. Harris (1985) points out that voluntarily imposed restrictive measures on exports when regarding price competition encourage local industries to become the price leader. This induces an increase in prices and profits for firms in the industry at the expense of consumers who will find a decrease in their purchasing power and welfare level. The measures taken to counter COVID-19 would induce macroeconomic costs materialize in supply and demand shocks (Boissay \& 
Rungcharoenkitkul, 2020). To limit the risks of contagion from COVID-19, workers avoid social interactions by reducing both labor supply (negative supply shock) and consumption (negative demand shock). Theoretically, the analysis of the occurrence of COVID-19 can also be discussed in the framework of the aggregate supply-aggregate demand (AS/AD) model in which $\mathrm{AD}$ is a decreasing function of the general price level.

While these measures aim to limit the health and economic impacts of COVID-19, some measures have mixed results. Bayham and Fenichel (2020) show that beyond the economic costs induced by the school closures in the United States, they create involuntary childcare obligations in families, particularly those in the health sector. Emeto et al. (2021) find that the implementation of border closures within African countries (South Africa, Nigeria, Ghana, Egypt, and Kenya) had minimal effect on COVID-19.

Economically, the pandemic has affected all regions of the world, but with varying intensity. Coguic and Osman (2021) show that Africa's real GDP declined for the first time in over thirty years by $2.6 \%$ in 2020 , and GDP per capita contracted by $4.7 \%$ due to the closure of borders, confinements, and dependence on extractive commodities. Also, sub-Saharan Africa experienced an economic decline of $-2.5 \%$ in 2020 , but less severe than Europe (-7.6\%), Latin America (-7.6\%), and South and Southeast Asia (-6.4\%), which recorded the largest declines in national income in 2020. While East Asia, which was the first region affected, has managed to stabilize (Chancel et al., 2021).

Most of the work on the economic consequences from COVID-19 has focused on the immediate effects (Correia et al., 2020). Yet, the effects of a pandemic are not only limited to the short term (Estrada, 2020) because of the irreversibility effects that characterize some decisions. Jordà et al. (2021) argue that the major pandemics of the last millennium have generally been associated with low asset returns for a long period. Similarly, Aazi et al. (2020) observe that the COVID-19 shock tested the different components of the affected economies for a long period, thus jeopardizing the return to normal in the short run.

Coguic and Osman (2021) identify three main channels of transmission of the COVID-19 shock to African economies: (i) the fall in the price of extractive commodities due to Africa's continuous dependence which constitute $55 \%$ of total African GDP; (ii) the closure of borders affecting the foreign exchange earnings and supply of countries; and, ultimately, (iii) containment measures in some countries and the lockdown of economic activities combined with weak state response capacities. Figure 1 describes one channel of transmission of the COVID-19 shock to demand through a temporary halt in economic activity that is likely to lead to job losses, a reduction in household purchasing power, and a contraction in investment and consumption, particularly in countries where social protection is almost non-existent. 
Figure 1. Mechanisms of transmission of COVID-19 pandemic shock

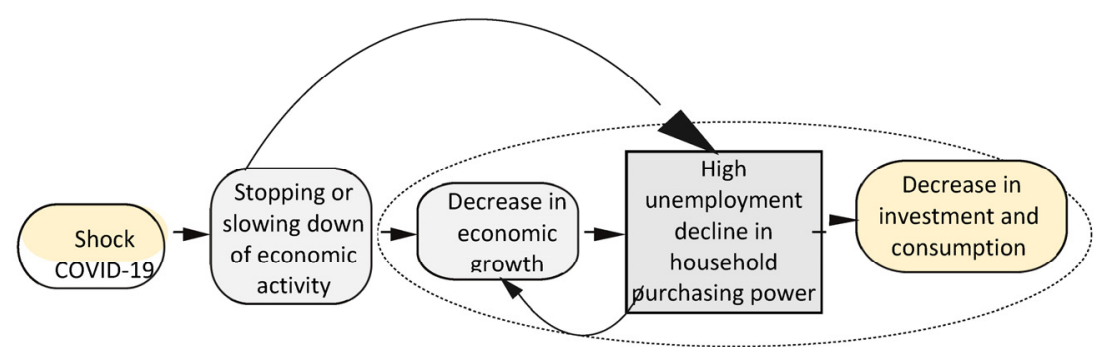

Source: Authors, using Suryahadi et al. (2020)

Boissay and Rungcharoenkitkul (2020) point out that interactions between supply and demand transmission channels are not specific to COVID-19 but rather a general feature of pandemic shocks. Thus, the resulting human losses lead to substantial and persistent economic losses. Consequentially, the significant costs of travel restrictions prove to be economically beneficial for preserving human capital (Baldwin \& Mauro, 2020).

The results show that the sectors most affected by COVID-19 are labor-intensive. Thus, non-essential services were more vulnerable to the restriction measures, which were locked down to limit human interaction and the virus' spread (Haddad et al., 2021). These abrupt changes have caused a return to trade protectionism that constitutes bottlenecks in food supply chains (Erokhin \& Gao, 2020; Larue, 2021).

However, the magnitude of the pandemic's economic impact on a region depends on the economic structures. It is strongly differentiated according to the sectors of activity (Estrada, 2020; Haddad et al., 2021; Martin et al., 2020). Thus, economies that rely more on the agricultural sector and foreign trade are more affected (Djiofack Zebaze et al., 2020). For Haddad et al. (2021), who discussed the state of São Paulo, non-essential services were more vulnerable than essential services (especially public health), agriculture, and manufacturing industries.

Unilateral containment measures of the pandemic, without cooperation in an ensemble framework and consisting of tightening trade restrictions, worsen the economic effects. The OCDE (2020) report states that world trade collapsed in the first half of 2020, falling by more than $15 \%$ from its 2019 level due to trade restrictions. Export restrictions are common factors influencing strategic trade policies. Thiam et al. (2021) show that bilateral restrictions between countries during the pandemic are inappropriate because they lead to a decrease in the total production of medical goods. In contrast, the number of medical goods available in an exporting country increases when restrictions are unilateral, reflecting good management. Also, Coulibaly (2021) supports the thesis of regional cooperation of government measures in containing the pandemic. These results indicate that world food and oil prices positively affect the consumer price index in the WAEMU region. 
Alongside African partners' production difficulties, trade barriers have contributed to increasing transport time, which has reduced intra-African trade flows. Moreover, the requirement for more thorough sanitary controls has not been matched by an increase in control staff, resulting in higher transport costs due to the intensive controls imposed at cross-border and the long travel and clearance times (Dicko, 2020).

Some of the empirical work on economic policies to mitigate and/or stimulate the economy following the pandemic's negative economic impacts has focused on the cyclical measures taken by governments at the national level. These economic policies are mainly based on fiscal instruments. This is what Fe and Ahoure (2021) have proposed by showing that the public measures implemented in Côte d'Ivoire have mitigated the impact of COVID-19 on the economy. They point out that these measures included the release of special funds to assist the most affected businesses such as those in tourism, transport, and hospitality, the establishment of moratoriums on the payment of taxes, the creation of special funds for small and medium-sized enterprises, including the informal sector, the purchase of food for emergency food aid, and the provision of cash transfers to the most vulnerable households. As for the policies' effectiveness, the authors find that they are sensitive to the shock on the labor supply of unskilled workers. Therefore, they argued that any policy aimed at reducing the effect of the pandemic on hours worked is more likely to mitigate the negative impact of the pandemic and foster economic resilience (Suryahadi et al., 2020).

Guerrieri et al. (2020) show that in a multi-sector economy with incomplete markets, firm shutdowns, and job losses amplify the negative effect of a Keynesian supply shock on economic activity. The authors examine the effects of various economic policies for economic stimulus and find that conventional fiscal stimulus may be less effective than usual because some sectors, being shut down, reduces the Keynesian multiplier feedback effect. Similarly, Morsy et al. (2021), in a first phase simulating the macroeconomic effects of COVID-19 in Africa, find that the pandemic would lead to an economic recession and widen fiscal deficits due to the contraction in the level of employment in the formal and informal sectors, including household consumption. In a second phase, Morsy et al. (2021) explore the different types of fiscal measures implemented by African countries to limit the economic impacts of the disease. The authors find that all fiscal policy instruments succeed in increasing household consumption and income, thus mitigating the effects of Africa's health crisis.

Figure 2 illustrates the mechanism, by which the pandemic containment measures affect and increase transport margins. It also highlights the relationship between export and import volumes including export taxes or subsidies and import tariffs. AfCFTA represents a removal of tariffs. When authorities take measures that restrict free movement (COVID-19 effects), they contribute to higher transport margins, and hence higher trade costs, because of the resulting rise in export prices. As a result, export demand falls. However, when countries adopt coordinated trade policies, such as the AfCFTA (total elimination of tariffs), this reduces trade costs. 
Figure 2. Trade channel of transmission of COVID-19 and AfCFTA measures

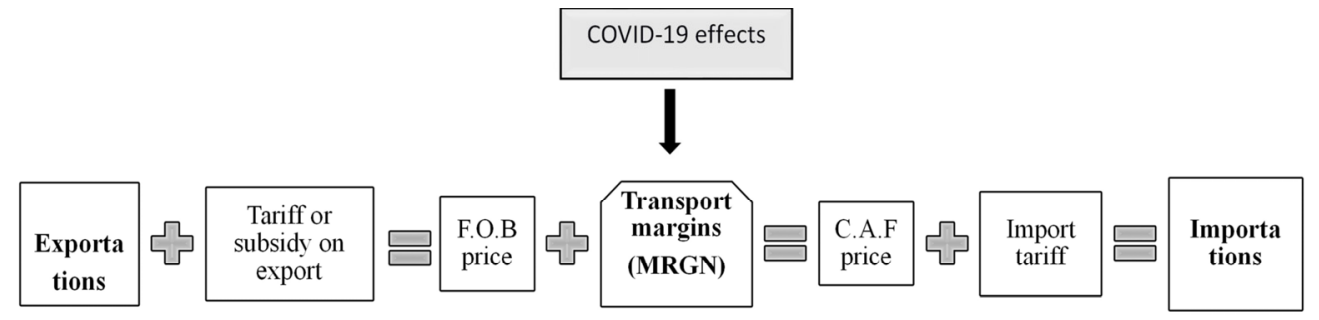

Source: Authors using Aguiar et al. (2016)

Figure 3 describes the interaction between the COVID-19 shock and the implementation of the AfCFTA on African economies. The transmission effects of COVID-19 are mediated by the sanitary measures imposed (red arrow). These measure negative impacts on economic activity. They have had negative economic consequences on economic growth (-2.6\% in 2020), incomes, and food supply (Chancel et al., 2021; Coguic \& Osman, 2021; Debuquet et al., 2020). The sudden decline in economic growth increases poverty (Suryahadi et al., 2020) due to falling incomes and job losses. This leads to a decline in household consumption and business investment while the AfCFTA reduces the costs of sourcing consumer goods for households and the costs of inputs and capital for firms (green arrow). The AfCFTA stimulates economic activity and growth through an increase of consumption and investment that leads to job creation. Depending on the redistributive impacts, the net effect of COVID-19 combined with implementing the AfCFTA depends on the magnitude of each.

Figure 3. Transmission Mechanism: From COVID-19 shock and the implementation of the AfCFTA to economic growth

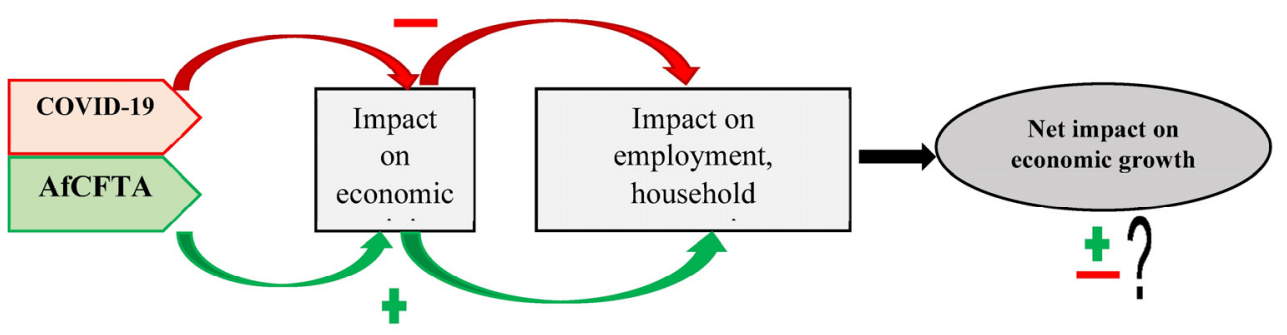

Source: Authors 


\section{Methodology}

\section{A. Data and simulations}

This study uses the latest Global Trade Analysis Project database (GTAP, version 10.2; 2014), which describes global bilateral trade patterns, production, consumption, and use of intermediate goods and services. To better understand the structural effects of shocks, the database ${ }^{3)}$ has been grouped into 33 industry sectors.

Three scenarios were simulated. The first scenario, "COVID-19," assumed increased trade costs due to border controls, personal travel restrictions, and curfews. These measures disrupted logistics and transportation. Following the WTO (2020) assumptions on the aggregation of indirect economic costs due to COVID-19, we assume that in Africa, COVID-19 increases trade costs of goods and services by $20 \%$. Indeed, WTO (2020) calculations show that transportation and service costs, alongside transportation costs for specialized equipment, increased by $22.5 \%$ over 12 months.

Additionally, air freight has increased by $70 \%$ in 2020 due to reduced air transport capacity. The "COVID-19" scenario captures the impact of COVID-19 in Southern and Northern Africa without mitigation measures.

The second scenario, "COVID-19+AfCFTA," is based on the first scenario and explores the implementation of the AfCFTA. The implementation of the AfCFTA consists of the complete elimination of intra-African tariffs in line with the final objective of the agreement. The results of the two scenarios are compared and analyzed.

The third scenario, "AfCFTA post COVID-19," explores the potential effects of the AfCFTA agreement without the measures (trade restrictions, containment ...) taken to protect public health. This scenario begins in 2024 with the complete removal of tariffs on exports and imports to Africa. The disease containment measures are assumed to be temporary.

\section{B. General description}

A dynamic multi-sector, multi-regional CGE model is used to assess the economic impact of COVID-19 containment measures on the Southern and Northern African economies. This model is theoretically based on the Partnership for Economic Policy (PEP-w-t) model by Lemelin et al. (2013). It can identify the different economic interactions in a given area and the mainshock transmission chains. The methodology presented here has already been used to assess the economic effects of COVID-19 (Banque Mondiale, 2020; Chitiga-Mabugu et al., 2021; Djiofack Zebaze et al., 2020; Madai Boukar et al., 2021; McKibbin \& Fernando, 2021; Zidouemba et

3) See Badri et al. 2015. for more details on the GTAP database 
al., 2020). These authors believe that the CGE model is appropriate for simulating the impact of an economic shock. It allows the direct and indirect effects of the pandemic to be evaluated in the medium term while allowing for both macroeconomic and sectoral effects. Also, this model is suitable for evaluating trade policies (Fouda Ekobena et al., 2021; Hamid \& Aslam, 2017; Mold \& Mukwaya, 2017; Zidouemba \& Jallab, 2021). It implements the interaction between different consumption and production behaviors while ensuring broad macroeconomic equilibria.

In the CGE model, the production structure of a regional economy is illustrated in Figure 4 and the consumption structure in Figure 5. Firms use land, labor, capital, and natural resources as factors of production. They combine these factors with intermediate inputs to produce goods in each region. This output is consumed by households, governments, and private and public sectors for investment. The rest of the output is exported.

Figure 4. Nested production structure

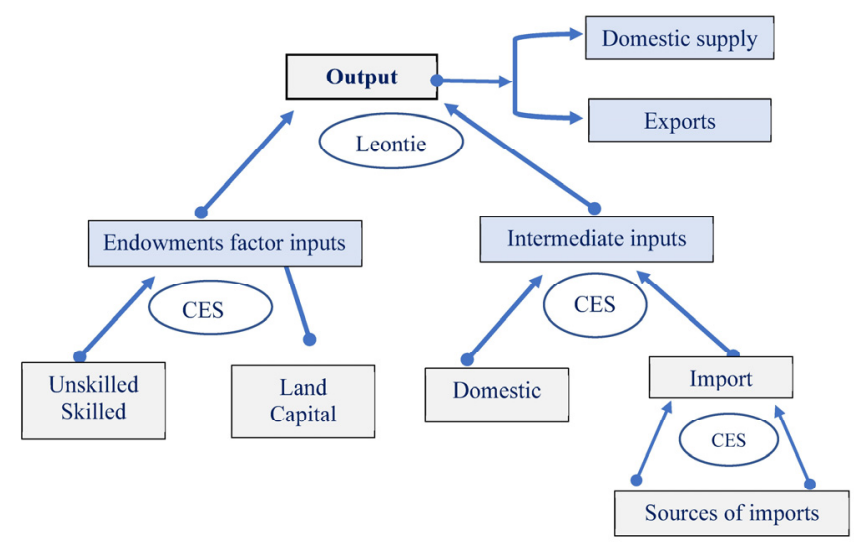

Source: Authors

Figure 5. Consumption structure

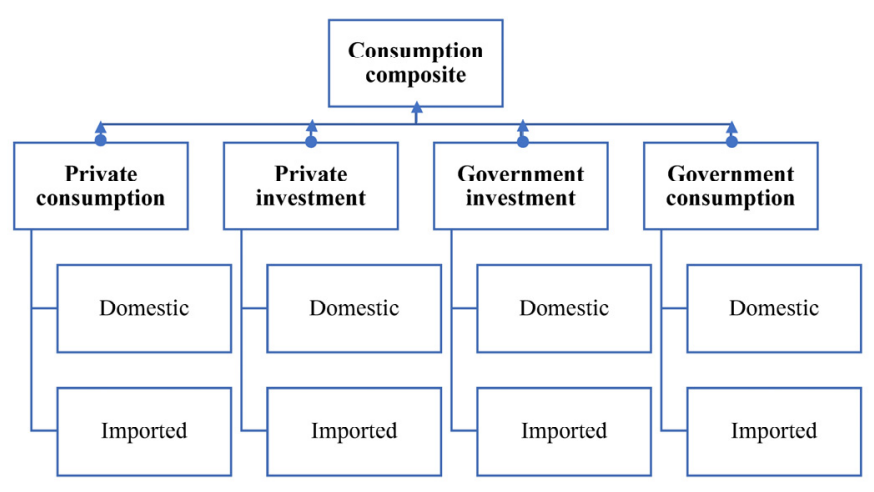

Source: Authors 
In this model, firms are assumed to operate in a perfectly competitive environment. Their objective is to maximize profits or minimize production costs regarding the technological constraints of their products but also to the prices of goods and services and factors. The government collects taxes and makes public expenditures. The household agent receives income from labor and capital and makes private expenditures. Taxes on goods and services imports, income, and production constitute the fiscal instruments. Taxes on imports of goods and services are applied to the value of sales, which already includes trade and transport margins, and customs duties. The consumption of households, public administrations, and intermediaries, and investments constitute the domestic demand for imported or domestically produced goods. Producers allocate their products to markets to maximize profits. The behavior of producers follows production functions of constant elasticity.

Three trade outlets contain the overall production in the economy, namely exports, domestic, and international transport margins. Exports are distributed across countries or regions of destination. Under the assumption that goods are heterogeneous (the functional forms are constant elasticity of substitution (CES) production functions), producers and consumers respond to symmetric behavior since it is assumed that imports from one region are imperfectly substitutable to imports from another region and that local products are imperfect substitutes for imported products. The macroeconomic equilibria, closures, and dynamics of the CGE model are in Appendix 1.

The direct effect of an increase in transaction costs (the tmrg parameter in equation [1]) is an increase in the price of imports and exports (equation [2]). This could therefore result in a drop in import demand (equation [2]), including for finale consumption, intermediate consumption goods (equation [3a]), and investment demand (equation [3b]) likely have negative effects on domestic production of goods and services (equation [4]). The increase in export prices will have the effect of lowering the price competitiveness of region's exports and could ultimately induce a fall in national production and overall economic growth. Whereas, the tariff dismantling, which consists of the elimination of customs duties (equalization of the parameter ttim to zero in equation [1]) will have the effect of producing the opposite effect of reducing the world price of imports, which would benefit private consumption and national production through increased demand for intermediate consumption and investment goods. The final effect can only be measured in a general equilibrium framework, which justifies the relevance of using the multi-region CGE model. Individuals interested in a complete description of the model can refer to Lemelin et al. (2013).

The price paid in region $z$ for imports from region $z j$ is the world price paid by $z$ for imports from $z j$, translated into region $z$ 's currency, plus taxes and duties on imports, margins, and domestic indirect taxes:

$$
P M_{i, z j, z}=\left(1+t t i c_{i, z}\right)\left(1+t t i m_{i, z j, z}\right) e_{z}\left[P W M_{i}+\sum_{i j} P W M G_{i j} t t m r g_{i j, i, z j, z}\right]
$$


$P M_{i, z j, z}$ : Price of commodity $i$ imported from region $z j$ by region $z$ (including margins and all taxes and duties); $P W M_{i, z j, z}$ : World price of commodity $i$ imported from region $z j$ by region $z$ (expressed in international currency); $P W M G_{i}$ : World price of margin I (expressed in international currency); ttic $c_{i, z}$ : Tax rate on commodity $i$ in region $z$; $t i m_{i, z j, z}$ : Rate of taxes and duties on imports of commodity $i$ from region $z j$ by region $z$; ttix $x_{i, z j, z}$ : Export tax rate on commodity $i$ exported to region $z j$ by region $z$.

Demand functions of imports from individual regions are derived from the first-order conditions of expenditure minimizing subject to the CES aggregator function. We have:

$$
I M_{i, z j, z}=\left[\frac{\beta_{i, z j, z}^{M 2} P M T_{i, z}}{P M_{i, z j, z}}\right]^{\sigma_{i, z}^{M 2}} \frac{I M T_{i, z}}{\left(\beta_{i, z}^{M 2}\right)^{1-\sigma_{i, z}^{M 2}}}
$$

Where $\sigma_{i, z}^{M 2}$ : Elasticity of substitution (CES - composite import); $P M T_{i, z}$ : Price of composite commodity $i$ imported by region $z$ (including all taxes, duties, and margins); $I M T_{i, z}$ : Quantity demanded of imports of composite commodity $i$ by region $z$ from all other regions.

$$
C I_{j, z}=i o_{j, z} X S_{j, z}
$$

Where $C I_{j, z}$ : Total intermediate consumption of industry $j$ in region $z$; $i o_{j, z}$ : Coefficient (Leontief-intermediate consumption) and $X S_{j, z}$ : Total output of industry $j$ in region $z$.

Investment demand refers to gross fixed capital formation (GFCF), which is distributed among commodities in fixed shares:

$$
P C_{i, z} P C_{i, z}=\gamma_{i, z}^{I N V} I T_{, z}
$$

Where: $I T_{z}=P K_{z} \sum_{k, j} I N D_{k, j, z}$ and $P K_{z}=\frac{1}{A_{z}^{k}} \prod i\left(\frac{P C_{i, z}}{\gamma_{i, z}^{I N V}}\right)^{\gamma_{i, z}^{I N V}} ; I T_{z, t}$ represents Real GFCF in region $z, P K_{z}$ : Price of new capital in region $z$ and $A_{z}^{k}$ : Scale parameter (price of new capital); $\gamma_{i, z}^{I N V}$ : Share of commodity $i$ in region $z$ total investment expenditures; $I N D_{k, j, z}$ Volume of new type $\mathrm{k}$ capital investment to industry $j$ in region $z . P C_{i, z}$ Purchaser price of composite commodity $i$ (including all taxes and margins) in region $z$.

The section on production describes how, in each region, industries combine inputs to produce total aggregate output $X S_{i, z}$. Producers allocate output to market outlets to maximize sales revenue, given product prices. The total output of industry $j$ in region $z\left(X S_{j, z, t}\right)$ : 


$$
X S_{i, z}=B_{i, z}^{X 1}\left[\beta_{i, z}^{E X_{-} X 1} E X T_{i, z}^{\rho_{i, z}^{X 1}}+\beta_{i, z}^{D-X 1} D S_{i, z}^{\rho_{i, z}^{X 1}}+\left(1-\beta_{i, z}^{E X_{X 1}}-\beta_{i, z}^{D-X 1}\right) M R G N_{i, z}^{-\rho_{i, z}^{X 1}}\right]^{-\frac{1}{\rho_{i, z}^{X 1}}}
$$

Where: $E X T_{i, z}$ : Supply of composite commodity $i$ by region $z$ to the export market; $D S_{j, i, z, t}$ : Supply of commodity I to the domestic market of region $z ; \beta_{i, z}^{X 1}$ : Scale parameter (CET-composite supply); $\beta_{i, z}^{D_{X 1}}$ : Domestic market share parameter (CET - composite supply); $\beta_{i, z}^{E X \_X 1}$ : Export share parameter (CET - composite supply); $\rho_{i, z}^{X 1}:$ Elasticity parameter (CET composite supply; $M R G N_{i, z}$ : Domestic production of commodity $i$ in region $z$ exported as international margin.

\section{Results and Discussion}

\section{A. Descriptive statistics and stylized facts}

The IMF's 2020 Regional Economic Outlook for sub-Saharan Africa stated, "Sub-Saharan Africa is facing an unprecedented health and economic crisis, which in just a few months has jeopardized years of hard-won development progress and disrupted the lives and livelihoods of millions." The evidence shows that African countries have beaten the alarmist predictions concerning their ability to cope with COVID-19.

\section{B. Focus only on South and North Africa}

Although some countries in Africa are severely affected by the virus, their health situation is not very alarming compared to other global regions. Notably, $76.02 \%$ of confirmed cases were in nine African countries including South Africa (34.07\%); Morocco (10.61\%); Tunisia (7.08\%); Ethiopia (5.55\%); Egypt (5.38\%); Libya (3.80\%); Kenya (3.49\%); Nigeria (3.40\%); and Algeria (2.64\%). 
Figure 6. Cumulative total cases per 100,000 population in Africa, 2 June 2021

\section{Cases - cumulative total per 100000 population}

WHO COVID19 AFRICA

$\square 22-192$

$\square 192-611$

$\square 611-1408$

$\square 1408-2936$

ए $2936-11895$
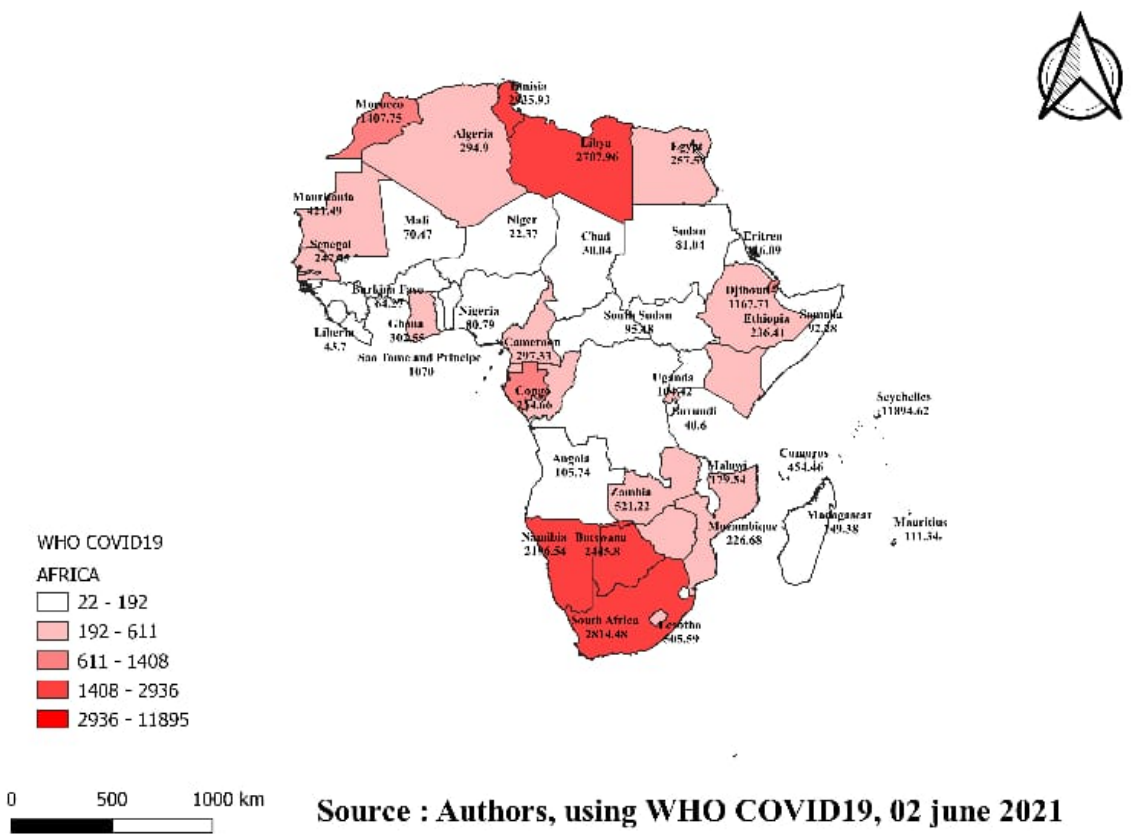

Source : Authors, using WHO COVID19, 02 june 2021

Figure 7. Death cumulative total per 100,000 population in Africa, 2 June 2021

Deaths - cumulative total per 100000 population

WHO COVID19

AFRICA

$\square 0,1-3,6$

$\square 3,6-10,8$

$\square 10,8-24,8$

$24,8-45,5$

$45,5-107,6$

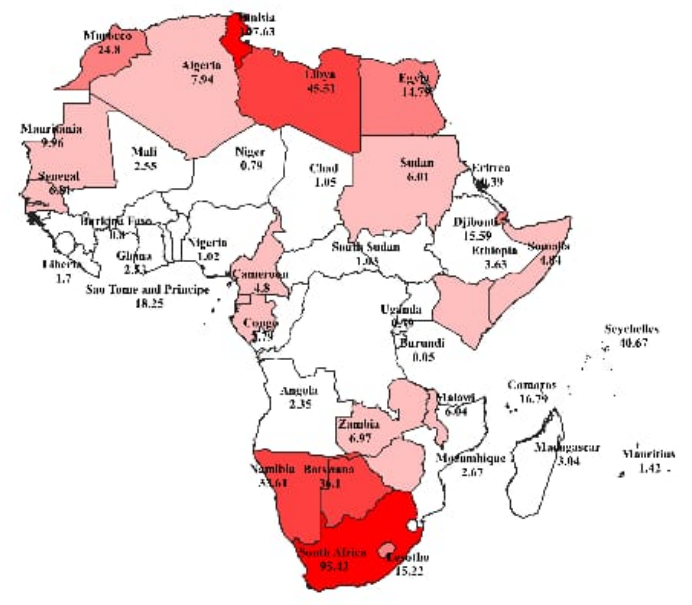

$\$$ 
Table 1 illustrates the situation of COVID-19 in North and Southern Africa. In North Africa, the countries most affected are Morocco (10.61\%), Tunisia (7.08\%), and Egypt (5.38\%). While in Southern Africa, more than 92\% of COVID-19 cases are in South Africa (Table 1).

Table 1. African Regional Distribution of Total Confirmed COVID-19 Cases as of 2nd June 2021

\begin{tabular}{lclc}
\hline \multicolumn{2}{c}{ North Africa } & \multicolumn{2}{c}{ Southern Africa } \\
\hline \multicolumn{1}{c}{ Country } & Proportion (en \%) en Afrique & Pays & Proportion (en \%) en Afrique \\
\hline Morocco & 10.61 & South Africa & 34.07 \\
Tunisia & 7.08 & Botswana & 1.17 \\
Egypt & 5.38 & Namibia & 1.14 \\
Libya & 3.80 & Eswatini & 0.38 \\
Algeria & 2.64 & Lesotho & 0.22 \\
Sudan & 0.73 & & \\
Total & $\mathbf{3 0 . 2 3}$ & & $\mathbf{3 6 . 9 9}$ \\
\hline
\end{tabular}

Source: Authors, using WHO (2021a) 4)

\section{Structure of intra-regional exports in Africa and recent export trends}

Table 2 shows that intra-regional trade in Africa remains structurally weak. While intraSouthern African trade was $13.51 \%$ in 2019 , in North Africa it barely reached 5.25\%. Southern Africa has experienced a significant increase in intra-area trade from $2.88 \%$ in $2000-2009$ to $14.31 \%$ in $2010-2019$.

Table 3 shows that a significant share of African exports is directed outside the continent. African countries do not trade enough among themselves because of the nature of their exports, which are mainly raw materials and less technological goods. The nature of the products exported (unprocessed and with low added value) would constitute a weakness in economic resilience to COVID-19.

Table 3 shows the average annual rate of change in exports in Africa. Over 2000-2018, the average rate of exports in North Africa (9.82\%) was above the African average $(9.81 \%)$ whereas Southern Africa (7.81\%) was below. In 2019, these rates ranged from $-5 \%$ to $-6 \%$ for these two subregions. There is a significant drop in African exports of $20.31 \%$ in 2020 . Consequently, while Southern Africa recorded a slight decline in these exports in 2020 compared to 2019 , this decline in North Africa was multiplied by almost five or $-27.61 \%$. This can be explained by the uncertainty linked to the coronavirus outbreak in China in December 2019 and by the negative economic consequences due to the containment measures taken by the authorities.

4) https://who.maps.arcgis.com/apps/dashboards/0c9b3a8b68d0437a8cf28581e9c063a9 
Table 2. Intra- and Extra-Trade of Country Groups by Product, (\% of Total), 2000-2019

\begin{tabular}{|c|c|c|c|c|c|c|c|c|c|}
\hline Year & & an 2000 & 2009 & & $\tan 2010$ & 2019 & & 2019 & \\
\hline PARTENAIRE & $\begin{array}{l}\text { Intra- } \\
\text { group }\end{array}$ & $\begin{array}{c}\text { Rest } \\
\text { Africa }\end{array}$ & $\begin{array}{l}\text { Rest of } \\
\text { the World }\end{array}$ & $\begin{array}{l}\text { Intra- } \\
\text { group }\end{array}$ & $\begin{array}{c}\text { Rest } \\
\text { Africa }\end{array}$ & $\begin{array}{l}\text { Rest of } \\
\text { the World }\end{array}$ & $\begin{array}{l}\text { Intra- } \\
\text { group }\end{array}$ & $\begin{array}{c}\text { Rest } \\
\text { Africa }\end{array}$ & $\begin{array}{l}\text { Rest of } \\
\text { the World }\end{array}$ \\
\hline Africa & 10.33 & & & 15.32 & & & 15.51 & & \\
\hline Northern Africa & 3.14 & 21.10 & 75.77 & 4.85 & 32.19 & 62.96 & 5.24 & 35.34 & 59.43 \\
\hline Sub-Saharan Africa & 13.57 & 4.38 & 82.05 & 18.06 & 3.62 & 78.32 & 17.79 & 4.19 & 78.03 \\
\hline Eastern Africa & 13.90 & 50.23 & 35.87 & 13.56 & 54.54 & 31.90 & 13.60 & 53.51 & 32.89 \\
\hline Middle Africa & 1.22 & 68.52 & 30.27 & 1.96 & 70.89 & 27.15 & 1.38 & 78.83 & 19.79 \\
\hline Southern Africa & 2.88 & 84.06 & 13.06 & 14.31 & 50.38 & 35.31 & 13.51 & 51.51 & 34.98 \\
\hline Western Africa & 9.00 & 34.30 & 56.70 & 8.24 & 44.80 & 46.96 & 7.08 & 47.15 & 45.77 \\
\hline
\end{tabular}

Source: Authors, using ${ }^{5)}$ CNUCED 2021

Table 3. Growth Rates of Comodities Exports in Africa, 2000-2020

\begin{tabular}{lcccc}
\hline \multicolumn{1}{c}{ Group } & Mean $2000-2018$ & 2018 & 2019 & 2020 \\
\hline Africa & 9.81 & 16.04 & -5.47 & -20.31 \\
Northern Africa & $\mathbf{9 . 8 2}$ & $\mathbf{1 9 . 1 8}$ & $\mathbf{- 5 . 8}$ & $\mathbf{- 2 7 . 6 1}$ \\
Southern Africa & $\mathbf{7 . 8 1}$ & $\mathbf{6 . 4 1}$ & $\mathbf{- 5 . 2 2}$ & $\mathbf{- 6 . 9 6}$ \\
Eastern Africa & 9.45 & 6.98 & -1.75 & -5.87 \\
Middle Africa & 13.61 & 23.22 & -19.38 & -28.79 \\
Western Africa & 10.97 & 21.81 & 3.49 & -24.58 \\
\hline
\end{tabular}

Source: Authors, using ${ }^{6)}$ CNUCED, 2021

Additionally, cooperative trade reforms such as the AfCFTA agreement stimulate economic growth, intra-regional trade, and human welfare (Valensisi et al., 2016; World Bank, 2020). The removal of tariff barriers is a crucial response to the crisis. Reducing the fiscal and administrative burdens on commercial actors improves the supply of goods and services (World Bank, 2020). Implementing such dismantling policies at this time, however, will only be effective if their gains outweigh the resultant losses.

\section{Results of simulations}

\section{Macroeconomics effects}

Table 4 presents the percentage changes in imports, exports, and total investment expenditures in Southern and Northern Africa over 2021-2023. The results show a significant decline of different magnitudes in imported and exported trade flows. COVID-19 has a greater impact on North Africa's economies than on Southern Africa's regarding foreign trade. Additionally,

5) https://unctadstat.unctad.org/wds/ReportFolders/reportFolders.aspx?sCS_ChosenLang=en

6) https://unctadstat.unctad.org/wds/ReportFolders/reportFolders.aspx?sCS_ChosenLang=en 
the drop in investment spending is higher in Southern Africa. This difference is explained by the structure of the economies of the two subregions (Table 2). It is also explained by the severity of restrictions on population mobility and policy responses to the crisis. On average, over 2010-2019 intra-regional exports accounted for 14.31\% of total exports in Southern Africa and $4.85 \%$ in North Africa. In addition, $35.31 \%$ of Southern Africa's export flows are directed to partners outside Africa who are unable to trade, compared to $62.96 \%$ for North Africa. The level of economic integration in Southern Africa is higher. Oil exporters have suffered severe terms of trade shock with the fall in external demand and a decline in world commodity prices, particularly for oil and gas (CEDEAO, 2020).

There has been a drastic decline in the level of investment in both subregions where Southern Africa has had a greater decline. The economic costs associated with restrictive measures to stop COVID-19 combined with the dependence of the supply chains of sub-regional industrial units on imported productive capital goods are at the root of the drop.

Furthermore, the operationalization of the AfCFTA is an instrument for mitigating the economic impacts of COVID-19. Trade liberalization in Africa reduces the negative economic consequences of the health crisis for trade in the two subregions. In contrast to foreign trade, the effectiveness of the AfCFTA amplifies the negative impacts of COVID-19 on investment in both zones, but more so in Southern Africa. Economic recovery in these subregions requires coordinated strategies at the regional level, alongside public support for the private sector that combines supply and demand-side measures.

Table 4. Estimated Regional Impacts, Variation in \%, 2021-2023

\begin{tabular}{|c|c|c|c|c|c|c|}
\hline \multirow[b]{2}{*}{ Year } & \multicolumn{2}{|c|}{ Importations } & \multicolumn{2}{|c|}{ Exportations } & \multicolumn{2}{|c|}{ Total investment } \\
\hline & COVID-19 & $\begin{array}{l}\text { COVID-19+ } \\
\text { ZLECAf }\end{array}$ & COVID-19 & $\begin{array}{c}\text { COVID-19 + } \\
\text { ZLECAf }\end{array}$ & COVID-19 & $\begin{array}{c}\text { COVID-19 + } \\
\text { ZLECAf }\end{array}$ \\
\hline \multicolumn{7}{|c|}{ North Africa } \\
\hline 2021 & -1.99 & -1.89 & -2.93 & -2.72 & -0.27 & -0.50 \\
\hline 2022 & -4.39 & -4.29 & -4.41 & -4.19 & -0.50 & -0.73 \\
\hline 2023 & -7.63 & -7.54 & -6.24 & -6.03 & -0.80 & -1.03 \\
\hline \multicolumn{7}{|c|}{ South Africa } \\
\hline 2021 & -0.64 & -0.74 & -1.64 & -1.59 & -1.01 & -2.38 \\
\hline 2022 & -2.23 & -2.29 & -2.41 & -2.33 & -1.50 & -2.89 \\
\hline 2023 & -4.56 & -4.59 & -3.37 & -3.26 & -2.14 & -3.54 \\
\hline
\end{tabular}

Source: Authors' simulations, GTAP 10.

Table 5 shows the effects of COVID-19 on intra-African exports by the three major sectors. The values are percentage changes for 2021. The results show that the loss of export volumes suffered by the economies is mainly through a decline of almost $27 \%$ in exports of agricultural 
products and a decline of about 7\% in regional exports of industrial goods. Services activities are affected less. These results corroborate Coguic and Osman (2021), who show that the closure of borders has caused some supply disruptions and severe consequences for the industrial and agricultural sectors that depend on imports of foreign inputs.

Implementing the AfCFTA during COVID-19 mitigates the negative impact of the pandemic on intra-regional trade. The AfCFTA increases exports of goods in the industrial sector by $3.47 \%$ and reduces the fall in exports from $27.28 \%$ (COVID-19 scenario) to $22.74 \%$ (COVID-19+ AfCFTA scenario) (Table 5).

Scenario 3 "AfCFTA post COVID-19" produces significant positive results for intra-African trade flows (Table 5), industrial production, and household consumption (Tables 9 and 10 in appendix). Compared to the COVID-19 context, the simulation results show that without the restrictive measures, the AfCFTA would lead to an increase in exports of $12.87 \%$ in the industrial sector and about $5 \%$ in agriculture. The positive effects obtained are explained by the facilitation of trade (especially the supply of goods and inputs at lower cost) caused by the removal of tariff barriers in Africa. The border control measures imposed to curb COVID-19 in Africa have interrupted the continent's progress of economic integration (with the entry into force of the AfCFTA on January 1, 2021).

Table 5. Estimated Impacts of COVID-19 and the AfCFTA on Intra-African Exports by Sectors, Variation (\%), 2021 (2024 for AfCFTA post COVID-19)

\begin{tabular}{lccc}
\hline \multicolumn{1}{c}{ Sectors } & COVID-19 & COVID-19 +AfCFTA & AfCFTA post COVID-19 \\
\hline Agriculture & -27.69 & -22.74 & 5.01 \\
Industry & -7.16 & 3.47 & 12.87 \\
Services & -0.518 & -0.6 & -0.18 \\
Mean Exportations & -10.23 & -2.36 & 5.90 \\
\hline
\end{tabular}

Note. Scenario 3 "AfCFTA post COVID-19" assumes the end of restrictive measures from 2024.

Source: Authors' simulations, GTAP 10.

\section{Sectoral impacts of COVID-19 and the AfCFTA}

Table 6 shows the sectoral effects of the virus containment measures on production and consumption. Table 7 shows the sectoral effects of COVID-19 on labor demand and capital demand by industry. The results are summarized through agriculture, industrial production, and services. The values are annual percentage changes relative to the baseline scenario over 2021-2023. They are calculated averages expressing annual variations in \%.

Tables 6 and 7 show that Southern Africa would be more affected than North Africa in sectoral production, household consumption, and factor demand. Details are presented in Appendix 2, Tables 9 and 10 . 
Table 6. Estimated Impacts of COVID-19 and the AfCFTA on Total Output of Industry and Consumption, Variation (\%), 2021-2023

\begin{tabular}{|c|c|c|c|c|c|c|c|c|}
\hline & \multicolumn{4}{|c|}{ Total output of industry in region } & \multicolumn{4}{|c|}{ Consumption of commodity by households } \\
\hline & \multicolumn{2}{|c|}{ South Africa } & \multicolumn{2}{|c|}{ North Africa } & \multicolumn{2}{|c|}{ South Africa } & \multicolumn{2}{|c|}{ North Africa } \\
\hline & $\begin{array}{l}\text { COVID-19 } \\
+ \text { AfCFTA }\end{array}$ & COVID-19 & $\begin{array}{l}\text { COVID-19 } \\
+ \text { AfCFTA }\end{array}$ & COVID-19 & $\begin{array}{l}\text { COVID-19 } \\
+ \text { AfCFTA }\end{array}$ & COVID-19 & $\begin{array}{l}\text { COVID-19 } \\
+ \text { AfCFTA }\end{array}$ & COVID-19 \\
\hline & \multicolumn{8}{|c|}{ Year 2021} \\
\hline Agriculture & -2.65 & -2.90 & 0.33 & 0.34 & 1.57 & -3.12 & 1.47 & -2.93 \\
\hline Industry & -0.26 & -1.34 & -0.12 & -0.26 & 0.82 & -4.10 & 0.81 & -3.58 \\
\hline \multirow[t]{2}{*}{ Service } & -0.20 & -0.24 & 0.15 & 0.18 & 0.44 & -1.95 & 0.62 & -1.48 \\
\hline & \multicolumn{8}{|c|}{ Year 2022} \\
\hline Agriculture & -4.08 & -4.40 & 0.47 & 0.48 & -7.45 & -4.79 & -9.07 & -4.08 \\
\hline Industry & -0.60 & -1.74 & -0.29 & -0.43 & -2.13 & -5.80 & -3.07 & -5.01 \\
\hline \multirow[t]{2}{*}{ Service } & -0.37 & -0.43 & 0.05 & 0.08 & 0.41 & -2.78 & 0.37 & -2.11 \\
\hline & \multicolumn{8}{|c|}{ Year 2023} \\
\hline Agriculture & -5.78 & -6.15 & 0.63 & 0.64 & 1.78 & -6.83 & 1.70 & -5.41 \\
\hline Industry & -0.95 & -2.14 & -0.50 & -0.64 & -3.29 & -7.82 & -3.84 & -6.69 \\
\hline Service & -0.63 & -0.69 & -0.15 & -0.12 & -4.75 & -3.79 & -6.33 & -2.89 \\
\hline
\end{tabular}

Source: Authors' simulations, GTAP 10.

Table 7. Estimated Impacts of COVID-19 and the AfCFTA on Demand for Labor and Capital by Industry, Variation (\%), 2021-2023

\begin{tabular}{|c|c|c|c|c|c|c|c|c|}
\hline & \multicolumn{4}{|c|}{ Demand for labor by industry } & \multicolumn{4}{|c|}{ Demand for capital by industry } \\
\hline & \multicolumn{2}{|c|}{ South Africa } & \multicolumn{2}{|c|}{ North Africa } & \multicolumn{2}{|c|}{ South Africa } & \multicolumn{2}{|c|}{ North Africa } \\
\hline & $\begin{array}{l}\text { COVID-19 } \\
+ \text { AfCFTA }\end{array}$ & COVID-19 & $\begin{array}{l}\text { COVID-19 } \\
+ \text { AfCFTA }\end{array}$ & COVID-19 & $\begin{array}{l}\text { COVID-19 } \\
+ \text { AfCFTA }\end{array}$ & COVID-19 & $\begin{array}{l}\text { COVID-19 } \\
+ \text { AfCFTA }\end{array}$ & COVID-19 \\
\hline & \multicolumn{8}{|c|}{ Year 2021} \\
\hline Agriculture & -4.21 & -4.56 & 0.50 & 0.51 & -1.70 & -1.87 & 0.03 & 0.04 \\
\hline Industry & -0.96 & -2.65 & -0.10 & -0.31 & -0.24 & -0.62 & -0.36 & -0.44 \\
\hline \multirow[t]{2}{*}{ Service } & -0.21 & -0.27 & 0.55 & 0.58 & -0.26 & -0.29 & -0.24 & -0.22 \\
\hline & \multicolumn{8}{|c|}{ Year 2022} \\
\hline Agriculture & -5.92 & -6.33 & 0.74 & 0.75 & -2.85 & -3.08 & 0.06 & 0.07 \\
\hline Industry & -1.16 & -2.81 & -0.04 & -0.24 & -0.55 & -1.07 & -0.67 & -0.77 \\
\hline \multirow[t]{2}{*}{ Service } & -0.31 & -0.39 & 0.68 & 0.70 & -0.55 & -0.58 & -0.51 & -0.48 \\
\hline & \multicolumn{8}{|c|}{ Year 2023} \\
\hline Agriculture & -7.84 & -8.30 & 1.02 & 1.03 & -4.24 & -4.52 & 0.08 & 0.10 \\
\hline Industry & -1.16 & -2.80 & 0.10 & -0.08 & -0.98 & -1.62 & -1.10 & -1.21 \\
\hline Service & -0.44 & -0.52 & 0.77 & 0.80 & -0.97 & -1.01 & -0.91 & -0.87 \\
\hline
\end{tabular}

Source: Authors' simulations, GTAP 10.

Table 8 reports the simulation results for "AfCFTA post COVID-19." The detailed results are in Table 10 (Appendix). 
Table 8. Estimated Impacts of the AfCFTA post COVID-19 by Sectors, Variation (\%), 2024-2026

\begin{tabular}{|c|c|c|c|c|c|c|c|c|}
\hline \multirow{3}{*}{$\begin{array}{c}\text { Sectors } \\
\text { impacts post } \\
\text { COVID-19 }\end{array}$} & \multicolumn{2}{|c|}{$\begin{array}{l}\text { Total output of } \\
\text { industry in region }\end{array}$} & \multicolumn{2}{|c|}{$\begin{array}{l}\text { Consumption of } \\
\text { commodity by } \\
\text { households }\end{array}$} & \multicolumn{2}{|c|}{$\begin{array}{c}\text { Demand for labor } \\
\text { by industry }\end{array}$} & \multicolumn{2}{|c|}{$\begin{array}{c}\text { Demand for capital } \\
\text { by industry }\end{array}$} \\
\hline & North & South & North & South & North & South & North & South \\
\hline & Africa & Africa & Africa & Africa & Africa & Africa & Africa & Africa \\
\hline & \multicolumn{8}{|c|}{ Year 2024} \\
\hline Agriculture & 0,00 & 0,34 & 0,06 & 0,35 & 0,00 & 0,39 & $-0,01$ & 0,31 \\
\hline Industry & 0,20 & 1,54 & 0,13 & 0,69 & 0,26 & 2,01 & 0,15 & 0,95 \\
\hline \multirow[t]{2}{*}{ Service } & $-0,04$ & $-0,09$ & 0,04 & 0,26 & $-0,02$ & $-0,15$ & $-0,05$ & $-0,04$ \\
\hline & \multicolumn{8}{|c|}{ Year 2025} \\
\hline Agriculture & $-0,01$ & 0,38 & 0,06 & 0,35 & 0,00 & 0,43 & $-0,01$ & 0,35 \\
\hline Industry & 0,20 & 1,59 & 0,13 & 0,69 & 0,26 & 2,01 & 0,16 & 1,07 \\
\hline \multirow[t]{2}{*}{ Service } & $-0,04$ & $-0,10$ & 0,04 & 0,25 & $-0,02$ & $-0,16$ & $-0,06$ & $-0,06$ \\
\hline & \multicolumn{8}{|c|}{ Year 2026} \\
\hline Agriculture & $-0,01$ & 0,41 & 0,05 & 0,36 & 0,00 & 0,46 & $-0,02$ & 0,38 \\
\hline Industry & 0,20 & 1,64 & 0,13 & 0,69 & 0,26 & 2,01 & 0,16 & 1,17 \\
\hline Service & $-0,05$ & $-0,11$ & 0,04 & 0,24 & $-0,02$ & $-0,16$ & $-0,07$ & $-0,08$ \\
\hline
\end{tabular}

Source: Authors' simulations, GTAP 10.

These results predict the economic vulnerability of North and Southern African industrial units if appropriate economic stimulus measures are not anticipated. They contradict Haddad et al.'s (2021) findings regarding São Paulo because of differences in economic structures.

Six major lessons can be drawn from the results:

1. A drastic decrease in household consumption can be observed in most sectors of activity. This decline is more significant in the industrial sectors due to the high dependence of the supply chains of sub-regional industrial units on imported raw materials. Containment measures are disrupting production value chains, resulting in job losses in labor-intensive sectors and a decline in household purchasing power. This combined effect leads to a decrease in domestic demand for manufactured goods that are already suffering from export constraints. Moreover, the decline in household consumption is also explained by the surge in consumer prices.

2. Demand for labor and capital factors falls significantly over 2021-2023 in Southern Africa and all sectors of activity than in North Africa due to the significant reduction in sectoral output and household consumption. The level of mitigation of the impacts of the crisis through the implementation of the AfCFTA is also lower in North Africa. In North Africa, the agricultural sector increased over the three years, while the industrial and services sectors did not because of the tourism and oil industries. To consolidate the resilience of the economies in the two subregions, it is necessary to implement differentiated support 
from the authorities in the medium term, at the national level to protect jobs in agriculture and industries as argued by Madai Boukar et al. (2021). This government support should target businesses and workers in times of confinement to ensure the continuity of economic activities and the restarting of businesses already closed due to COVID-19. Managers may consider paying partial unemployment benefits, which would help reinforce household purchasing power, keeping workers active and reviving household consumption, ultimately remedying the decline in the level of investment and wealth.

3. In Southern Africa, labor demand is falling significantly in rice, vegetables, fruits and nuts, sugar, processing as well as construction, other food, beverages, and tobacco products. While in North Africa, the decline is in fishing, gas distribution, water, meat products and other manufactured goods, vegetable oils and fats, transport equipment, and petrochemicals. However, activities timber, harvesting, and rice processing are experiencing an increase in labor demand. This is because the prices of these goods and the accompanying efforts of the public authorities are increasing. The decline in demand for labor and household consumption are explained by the collapse of economic activity and fear of contamination in marketplaces and containment measures as supported by Langot and Petit (2020).

4. Services have been negatively affected by COVID-19. Disruptions in the supply of services have important economic and trade consequences because the sector provides inputs for other economic activities. The results corroborate Fernandes (2020) who argued that service-based economies are more affected by the crisis and with a greater threat to jobs. As Arturo \& Estrada (2020) point out, consumption, retail, and service industries have been more impacted due to changes in consumer behavior.

5. Accounting for AfCFTA helps mitigate the negative economic impacts of COVID-19. Economic costs could be significantly minimized through the facilitation of procurement of capital goods and sanitary products. As such, McKibbin and Fernando (2021) emphasize the need for more investment in public health systems in all economies, especially those with high population density and less developed health care systems. Our results corroborate Djiofack Zebaze et al. (2020) and the World Bank (2020) on the need for regional coordination and cooperation of responses to the negative economic impacts of the health shock. Also, they complement Zidouemba and Jallab (2021) who show that all African regions experience an increase in exports of industrial and intermediate goods through the AfCFTA. For these authors, the AfCFTA is a catalyst for industrialization and structural economic transformation.

6. "AfCFTA post COVID-19" scenario indicates that, in the absence of the trade restrictions triggered by the pandemic, implementing the AfCFTA potentially produces positive effects in North and Southern Africa. Although the effects are mixed for services, the AfCFTA 
without restrictive measures produces positive effects for household consumption and input demand in the industrial and agricultural sectors. These results show that stricter sanitary border controls on the transport of goods, confinements, and border closures have contributed to declining economic growth in North and Southern Africa.

\section{Conclusion}

This paper focused on assessing the macroeconomic and sectoral impacts of COVID-19 on the North and Southern African economies, while analyzing the potential positive impact of the implementation of the AfCFTA on the economic impacts of COVID-19.

We used the PEP-w-t CGE model in the first scenario with the assumption that virus containment measures reduce trade due to increased trade costs. The second scenario assumes that the complete removal of intra-African tariff barriers is a response to mitigate the negative effects of the crisis in North and Southern Africa. The third scenario simulates the impacts of AfCFTA implementation on economic activity without the COVID-19 restrictive measures. The results show that COVID-19 has had and continues to have significant economic and social impacts. According to our results, the COVID-19 pandemic induces a contraction of economic activity in these subregions over 2021-2023 in the absence of coordinated economic recovery measures. Whereas, the AfCFTA mitigates the economic impact of the crisis.

Given the results, it is necessary to take appropriate measures to deal with the collapse of economic activity due to COVID-19. To this end, accelerating the implementation of the AfCFTA, coupled with improvements in trade infrastructure, would amplify the mitigating effects by reducing the economic impacts of the pandemic through the supply of consumer and capital goods. Additionally, policies to remove trade barriers would mitigate the decline in intra-African exports from an average of $10.23 \%$ (COVID-19 scenario) in 2021 to $2.36 \%$ (AfCFTA+COVID-19 scenario).

\section{References}

Aazi, F. Z., Audibert, M., Bouazizi, Y., Fekkaklouhail, S., Ikira, M., Masmoudi, H., Mourji, F. M., Nahmed, Z., Oudmane, M., \& Tamsamani, Y. Y. (2020). Crise sanitaire et répercussions économiques et sociales au Maroc: évaluations d'un collectif de chercheurs. évaluations d'un collectif de chercheurs. https:/hal shs.archives-ouvertes.fr/halshs-02925418/document

Aguiar, A., Narayanan, B., \& McDougall, R. (2016). An overview of the GTAP 9 data base. Journal of Global Economic Analysis, 1(1), 181-208. https://doi.org/10.21642/JGEA.010103AF 
Agyei, S. K., Isshaq, Z., Frimpong, S., Adam, A. M., Bossman, A., \& Asiamah, O. (2021). COVID-19 and food prices in sub-Saharan Africa. African Development Review, 33(S1). https://doi.org/10.1111/14 67-8268.12525

Arturo, M., \& Estrada, R. (2020). Economic Waves: The Effect of the Wuhan COVID-19 On the World Economy (2019-2020). Social Wellbeing Research Centre (SWRC). pp. 1-6.

Baldwin, R., \& Mauro, B. W. di. (2020). Mitigating the COVID Economic Crisis: Act Fast and Do Whatever It Takes. Centre for Economic Policy Research Press. pp. 1-24. https://voxeu.org/content/miti gating-covid-economic-crisis-act-fast-and-do-whatever-it-takes

Baldwin, R., \& Tomiura, E. (2020). The economic effects of a pandemic. In C. Press (Ed.), Economics in the Time of COVID-19 (pp. 59-71). Centre for Economic Policy Research Press. https://voxeu.org/co ntent/economics-time-covid-19

BanqueMondiale. (2020). Évaluation de l'impact économique du COVID-19 et des réponses politiques en Afrique subsaharienne. In Série Africa's Pulse (Vol. 21). Washington, DC.

Bayham, J., \& Fenichel, E. P. (2020). Articles Impact of school closures for COVID-19 on the US health-care workforce and net mortality: a modelling study. The Lancet Public Health, 2667(20), 1-8. https://doi.org/10.1016/S2468-2667(20)30082-7

Boissay, F., \& Rungcharoenkitkul, P. (2020). Macroeconomic effects of Covid-19: An early review. BIS Bulletin series, N0 7. Basel. https://www.bis.org/publ/bisbull07.pdf

Bouët, A., \& Laborde, D. (2020). COVID-19 and global food security. In J. Swinnen \& J. McDermott (Eds.), COVID-19 and global food security (pp. 69-72). Food trade.

CEDEAO. (2020). Pandémie De La Covid-19: Impact des mesures de restriction En Afrique de L'Ouest. Abuja: Rapport de la Commission de la CEDEAO.

Chancel, L., Piketty, T., Saez, E., \& Zucman, G. (2021). World Inequality Report 2022. Paris: World Inequality Lab.

Chitiga-Mabugu, M., Henseler, M., Mabugu, R., \& Maisonnave, H. (2021). Economic and Distributional Impact of COVID-19: Evidence from Macro-Micro Modelling of the South African Economy. South African Journal of Economics, 89(1), 82-94. https://doi.org/10.1111/saje.12275

Coguic, R. Le, \& Osman, Y. (2021). Les grandes tendances macroéconomiques de l'Afrique et de ses régions. In Agence française de développement (AFD) (Ed.), L'économie africaine 2021 (La Découve, pp. 7-24). AFD. https://cpccaf.org/files/zhbXMeEI6U-9yuVsPHmUfQ.pdf

Correia, S., Luck, S., \& Verner, E. (2020). Pandemics Depress the Economy, Public Health Interventions Do Not: Evidence from the 1918 Flu. SSRN Electronic Journal. https://doi.org/10.2139/ssrn.3561560

Debuquet, D. L., Martin, W., \& Vos, R. (2020). Impacts of COVID-19 on global poverty, food security and diets. IFPRI Discussion Paper, 01993. IFRPI. https://doi.org/10.2499/P15738COLL2.134229

Dicko, A. H. (2020). Économie des corridors ouest-africains : vers une nouvelle conception des services de transport intégrant les TIC. In M. LIHOUSSOU (Ed.), Gouverner ports, transports et logistique à l'ère du numérique (EMS, pp. 139-159). Collection Afrique Atlantique. https://www.sefacil.com/wpcontent/uploads/2020/10/gouverner-port.pdf

Djiofack Zebaze, C., Dudu, H., \& Zeufack, A. G. (2020). Évaluation de l'impact économique de la COVID-19 en Afrique subsaharienne: perspectives à partir d'un modèle d'équilibre général calculable 
(EGC). Revue Internationale de Politique de Développement, 12.2. https://doi.org/10.4000/poldev.3546 Emeto, T. I., Alele, F. O., \& Ilesanmi, O. S. (2021). Evaluation of the effect of border closure on COVID-19 incidence rates across nine African countries: an interrupted time series study. Transactions of The Royal Society of Tropical Medicine and Hygiene, 115(10), 1174-1183. https://doi.org/10.1093/trstmh/tr ab033

Erokhin, V., \& Gao, T. (2020). Impacts of COVID-19 on trade and economic aspects of food security: Evidence from 45 developing countries. International Journal of Environmental Research and Public Health, 17(16), 1-28. https://doi.org/10.3390/ijerph17165775

Estrada, M. A. R. (2020). COVID-19: Economic Recession or Depression? Estudios Económicos, 37(75), 139-148. https://doi.org/10.52292/j.estudecon.2020.1983

Fe, D. C., \& Ahoure, A. A. E. (2021). Les économies de l'UEMOA face à la pandémie de la Covid-19 : politiques économiques et Perspectives. Revue Economique et Monétaire, (29), 10-39.

Fernandes, N. (2020). Economic effects of coronavirus outbreak (COVID-19) on the world economy $\left(\mathrm{N}^{\circ}\right.$ WP-1240-E). http://dx.doi.org/10.2139/ssrn.3557504

FMI. (2020). Perspectives de l'économie mondiale: Le Grand Confinement. Report, Washington, D.C Fouda Ekobena, S. Y., Coulibaly, A. E., Keita, M., \& Pedro, A. (2021). Potentials of the African Continental Free Trade Area: A combined partial and general equilibrium modeling assessment for Central Africa. African Development Review, 33(3), 452-465. https://doi.org/10.1111/1467-8268.12594

Fouré, J., Bénassy-quéré, A., \& Fontagné, L. (2012). The Great Shift: Macroeconomic projections for the world economy at the 2050 horizon (No. 2012-03). http://www.cepii.fr/PDF_PUB/wp/2012/wp2012-03.pdf

Giammetti, R., Papi, L., Teobaldelli, D., \& Ticchi, D. (2020). The Italian value chain in the pandemic: the input-output impact of Covid-19 lockdown. Journal of Industrial and Business Economics, 47(3), 483-497. https://doi.org/10.1007/s40812-020-00164-9

Guerrieri, V., Lorenzoni, G., Straub, L., \& Werning, I. (2020). Macroeconomic Implications of COVID-19: Can Negative Supply Shocks Cause Demand Shortages? SSRN Electronic Journal Working Paper, 26918. https://doi.org/10.2139/ssrn.3570096

Haddad, E. A., Perobelli, F. S., Araújo, I. F., \& Bugarin, K. S. S. (2021). Structural propagation of pandemic shocks: an input-output analysis of the economic costs of COVID-19. Spatial Economic Analysis, 16(3), 252-270. https://doi.org/10.1080/17421772.2020.1844284

Hamid, M. F. S., \& Aslam, M. (2017). Intra-regional Trade Effects of ASEAN Free Trade Area in the Textile and Clothing Industry. Journal of Economic Integration, 32(3), 660-688. https://doi.org/10.1113 0/jei.2017.32.3.660

Harris, R. (1985). Why Voluntary Export Restraints Are 'Voluntary'. The Canadian Journal of Economics / Revue canadienne d'Economique, 18(4), 799-809. http://dx.doi.org/10.2307/135091

Jordà, Ò., Singh, S. R., \& Taylor, A. M. (2021). Longer-Run Economic Consequences of Pandemics. The Review of Economics and Statistics, 104(1), 1-10. https://doi.org/10.1162/rest_a_01042

Langot, F., \& Petit, P. (2020). Évaluation des politiques publiques: introduction. Revue Française d'économie, 35(1), 3-18. https://doi.org/https://doi.org/10.3917/rfe.201.0003

Larue, B. (2021). COVID-19 and labor issues: An assessment. Canadian Journal of Agricultural Economics/ Revue Canadienne d'agroeconomie, 69(2), 269-279. https://doi.org/10.1111/cjag.12288 
Lemelin, A., Robichaud, V., Decaluwé, B., \& Maisonnave, H. (2013). PEP-w-1: The PEP standard multiregion, single-period world CGE model (Ver. 4.0), PEP Research Network.

Madai Boukar, A., Mbock, O., \& Kilolo, J. M. (2021). The impacts of the Covid-19 pandemic on employment in Cameroon: A general equilibrium analysis. African Development Review, 33(S1). https://doi.org/10.1111/1467-8268.12512

Martin, P., Pisani-Ferry, J., \& Ragot, X. (2020). Une stratégie économique face à la crise. Notes Du Conseil d'analyse Économique, n57(3), 1. https://doi.org/10.3917/ncae.057.0001

McKibbin, W., \& Fernando, R. (2021). The Global Macroeconomic Impacts of COVID-19: Seven Scenarios. Asian Economic Papers, 20(2), 1-30. https://doi.org/10.1162/asep_a_00796

Mold, A., \& Mukwaya, R. (2017). Modelling the economic impact of the tripartite free trade area: Its implications for the economic geography of Southern, Eastern and Northern Africa 2 . Journal of African Trade, 3(1-2), 57. https://doi.org/10.1016/j.joat.2017.05.003

Morsy, H., Balma, L., \& Mukasa, A. N. (2021). 'Not a good time': Assessing the economic impact of COVID-19 in Africa using a macro-micro simulation approach. African Development Review, 33(S1). https://doi.org/10.1111/1467-8268.12526

NUCEA. (2020). Crise de la COVID-19 en Afrique du Nord: Impact et stratégies d 'atténuation. Rapport NUCEA. Addis.

OCDE. (2020). L'impact territorial du Covid -19: Gérer la crise et la reprise aux différents niveaux d'administration. In Rapport, Organisation de coopération et de développement économiques (OCDE). Paris. http://www.oecd.org/coronavirus/en/

PNUD. (2017). L'Afrique centrale : une région en retard? Rapport. Addis -Abeba, Ethiopie.

Rosenberg, J., Strauss, I., \& Isaacs, G. (2021). COVID-19 impact on SADC labour markets: Evidence from high-frequency data and other sources. African Development Review, 33(S1). https://doi.org/10.11 11/1467-8268.12528

Suryahadi, A., Al Izzati, R., \& Suryadarma, D. (2020). Estimating the Impact of Covid-19 on Poverty in Indonesia. Bulletin of Indonesian Economic Studies, 56(2), 175-192. https://doi.org/10.1080/0007491 8.2020 .1779390

Thiam, M., Brou, J. K., \& Varela, B. A. (2021). Export Restrictions and COVID-19. Journal of Economic Integration, 36(4), 519-548. https://doi.org/https://doi.org/10.11130/jei.2021.36.4.519

Tröster, B., \& Küblböck, K. (2020). Unprecedented but not Unpredictable: Effects of the COVID-19 Crisis on Commodity-Dependent Countries. The European Journal of Development Research, 32(5), 1430-1449. https://doi.org/10.1057/s41287-020-00313-9

UNECA. (2020). Faciliter le commerce transfrontalier par la coordination de la riposte africaine au COVID-19. Addis Ababe: Rapport UNECA.

Valensisi, G., Lisinge, R., \& Karingi, S. (2016). The trade facilitation agreement and Africa's regional integration. Canadian Journal of Development Studies, 37(2), 239-259. https://doi.org/10.1080/022551 89.2016.1131672

WHO. (2020). COVID-19 Strategic Preparedness and Response: Plan operational planning guidelines to support country preparedness and response. Report, Geneva.

World Bank. (2020). African continental free trade area. Report World Bank. https://doi.org/10.1596/978-1 
146 Journal of Economic Integration Vol. 37, No. 1

$-4648-1559-1$

WTO. (2020). Methodology for the wto trade forecast of april 8 2020. Report. Geneva.

Zidouemba, P. R., \& Jallab, M. S. (2021). The African Continental Free Trade Area and the trade facilitation agreement: some regional macroeconomic impacts. International Journal of Trade and Global Markets, 14(3), 325. https://doi.org/10.1504/IJTGM.2021.115723

Zidouemba, P. R., Kinda, S. R., \& Ouedraogo, I. M. (2020). Could Covid-19 Worsen Food Insecurity in Burkina Faso? The European Journal of Development Research, 32(5), 1379-1401. https://doi.org/1 0.1057/s41287-020-00324-6 


\section{Appendix}

\section{Appendix 1. Macroeconomic equilibria, closures, and dynamics of the CGE model}

For macroeconomic equilibria in the commodity and factor market, it is assumed that the balance between supply and demand is verified through the flexibility of the respective prices. In the baseline scenario, labor demand is assumed to be equal to labor supply, i.e., full employment in each region.

The CGE model brings together a system of equations that describes the economic links between several regions and sectors of activity at the global level. As for the model's closure rules, the endogenous and exogenous variables are determined. The values of the exogenous variables are fixed at their initial level while the values of the endogenous variables are determined during the resolution of the model. Also, prices and quantities are determined endogenously. The exchange rate of a region chosen as reference is the European region. Since there is no theoretical framework to choose between different closures, the choice of closure must be guided by the structure of the economy under study (Mold \& Mukwaya, 2017).

The dynamics of the model are recursive. The calibration of the baseline scenario is done by running a modified version of the model that is constrained to follow Fouré et al.'s (2012) projections of real GDP where total factor productivity (TFP) is endogenous. Aggregate labor supply and domestic savings rates are also fixed according to Fouré et al.'s (2012) projections. The solution value of total factor productivity and other exogenous variables (including savings rates) given by the modified version of the model is the baseline scenario. These variables are then exogenously fixed at their calibrated values.

Capital accumulation is endogenous in the model and thus does not follow the projections (Fouré et al., 2012). Therefore, the sectoral and regional capital stock is equalized to that of the previous period, minus depreciation, plus the volume of new capital investment in the previous period.

The quantity demanded of each type of capital in each region is equal to the quantity supplied. Capital is assumed to be region and sector specific. Total investment expenditure is equal to the sum of agents' savings. Labor is assumed to be mobile only between production sectors in the same region. Thus, labor can move between sectors, but not between regions. It is therefore assumed that the wage rate is defined by region within a geographically segmented labor market. 
148 Journal of Economic Integration Vol. 37, No. 1

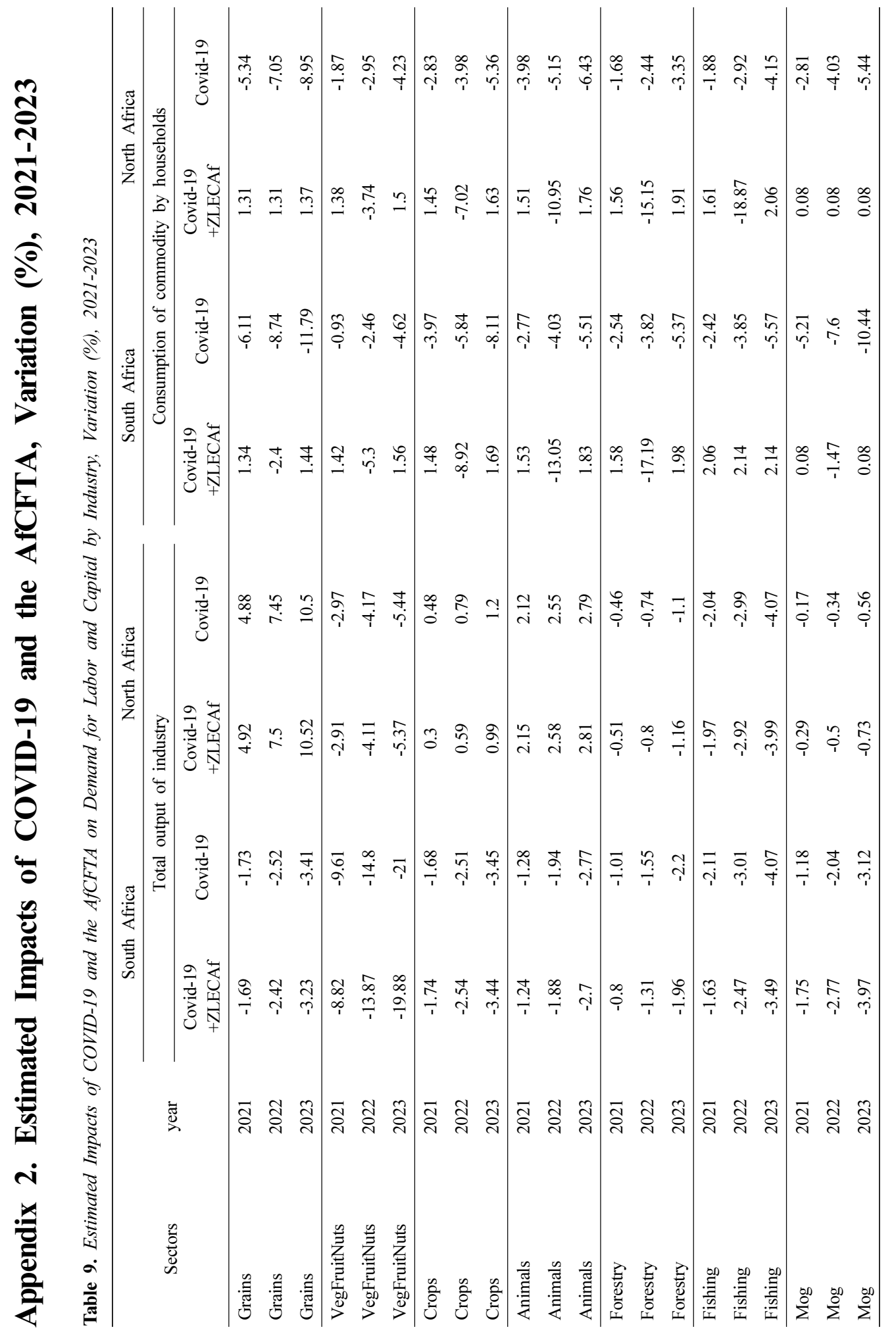




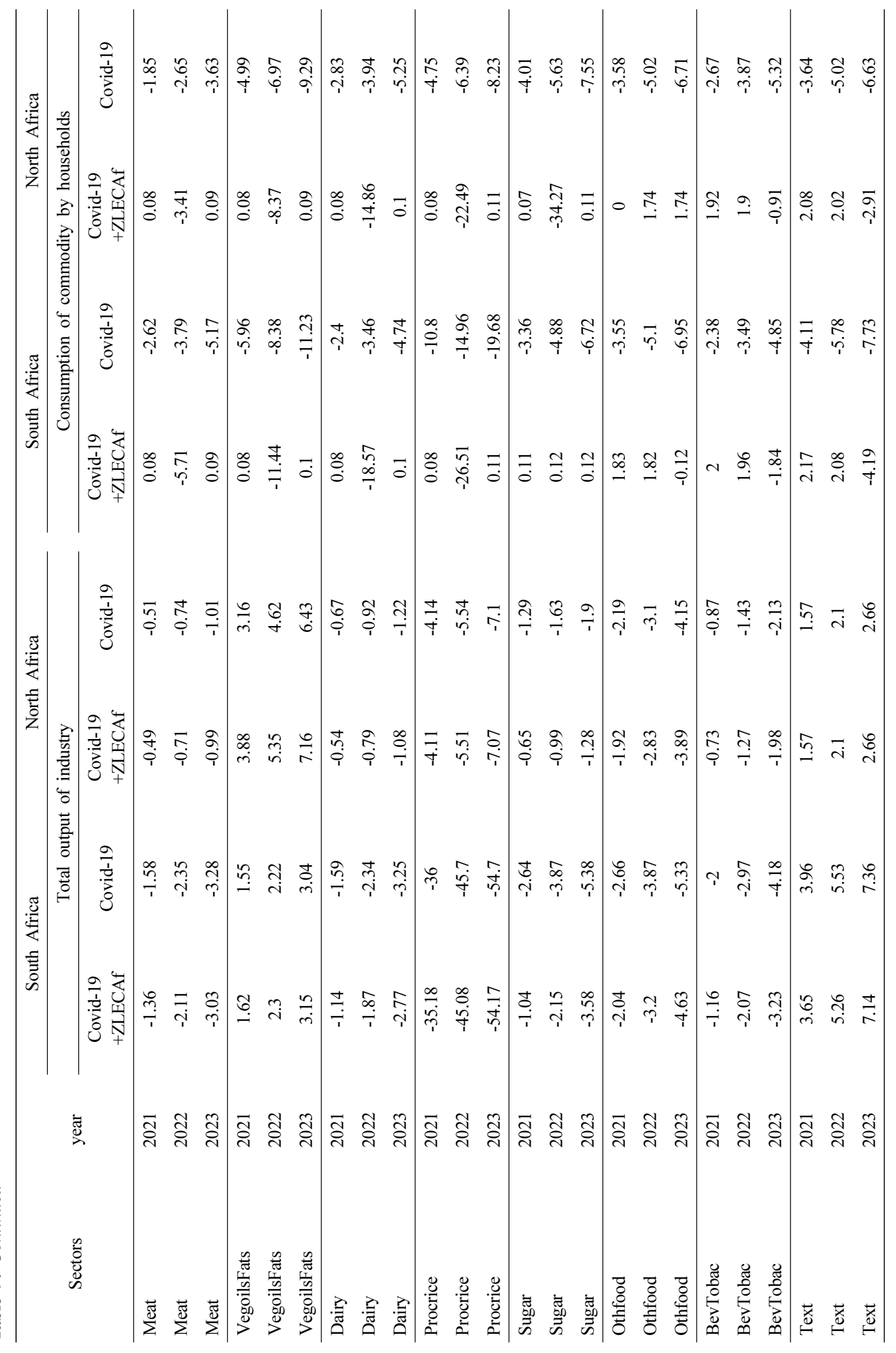




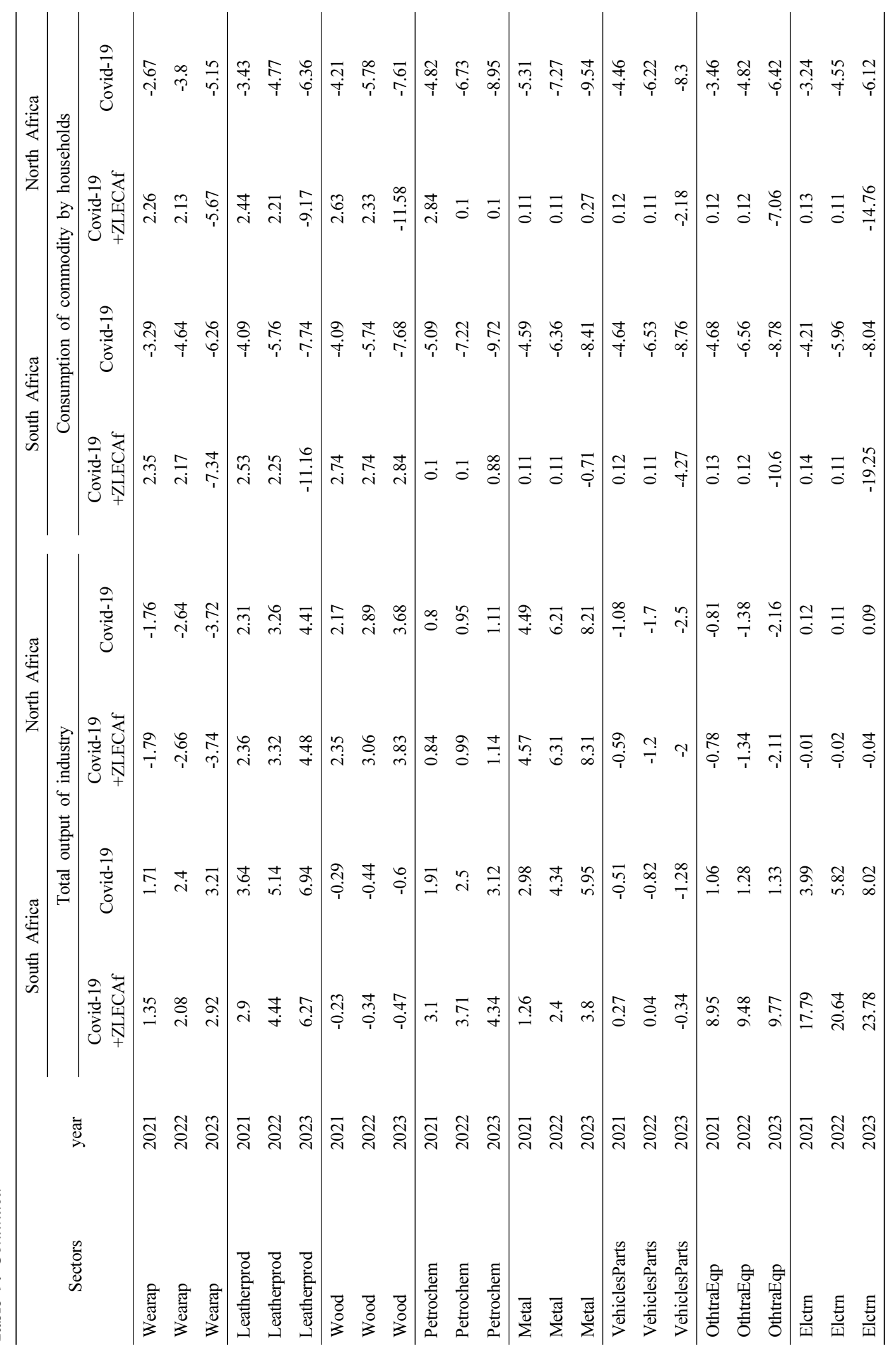




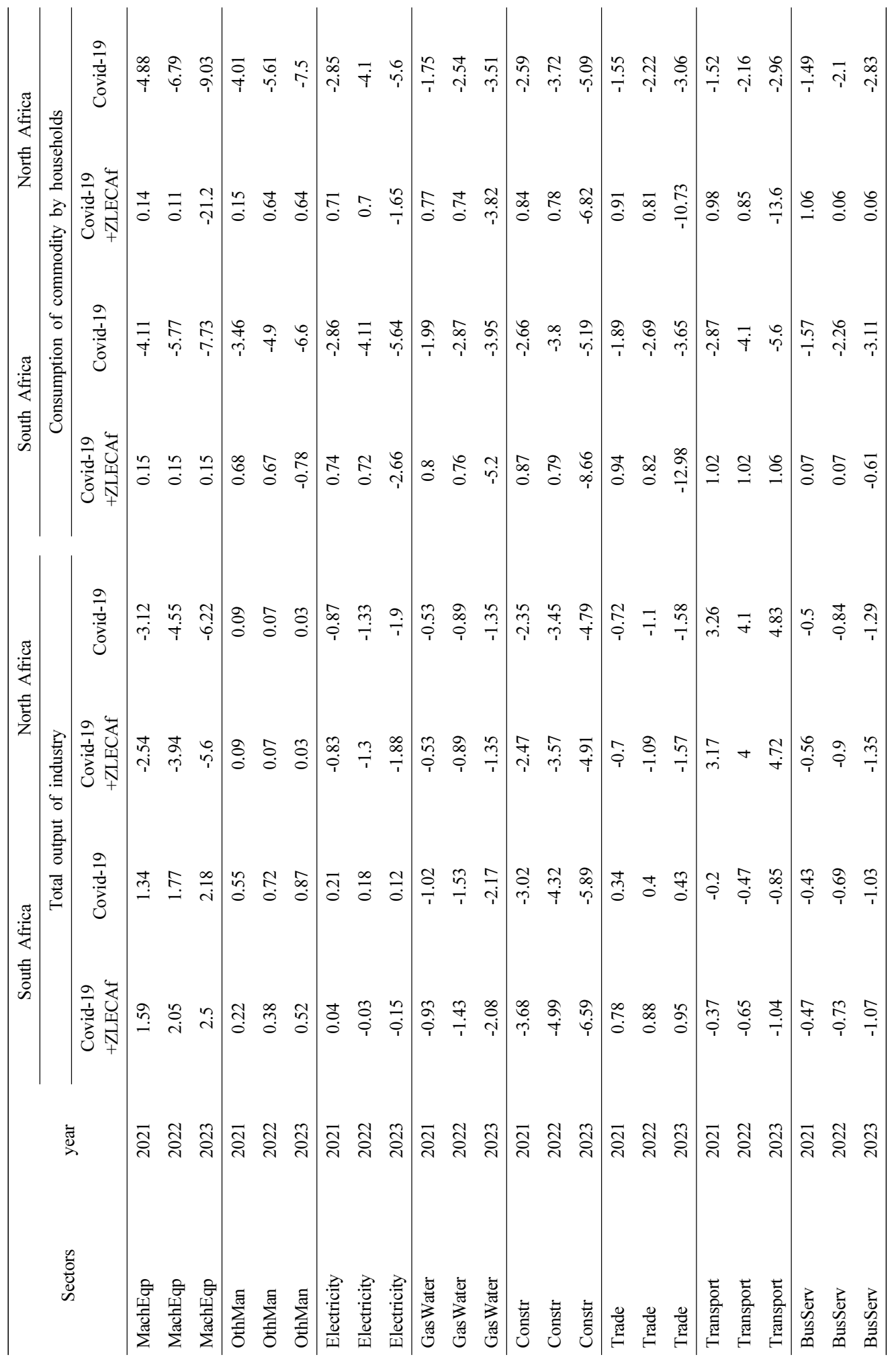




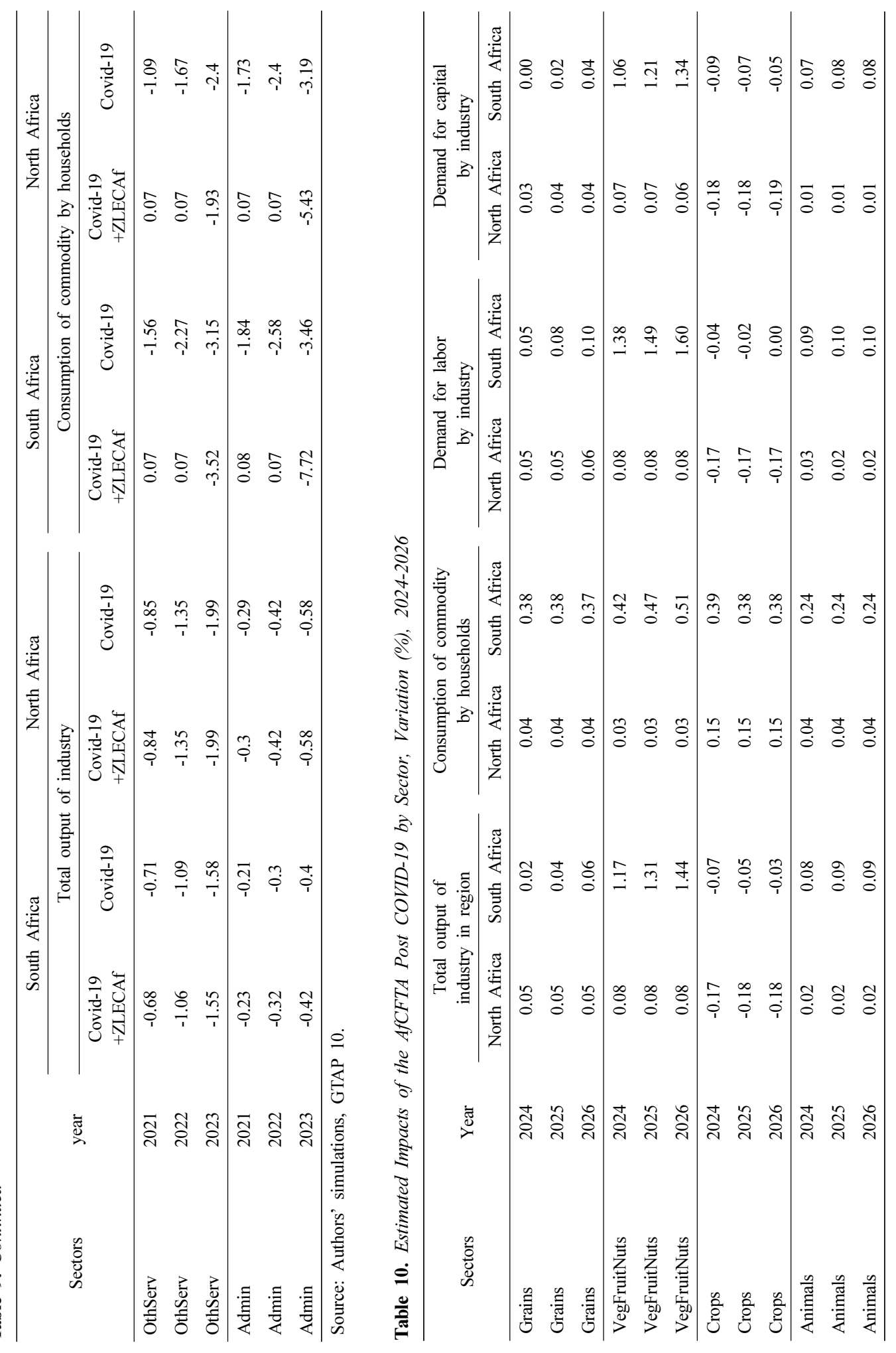




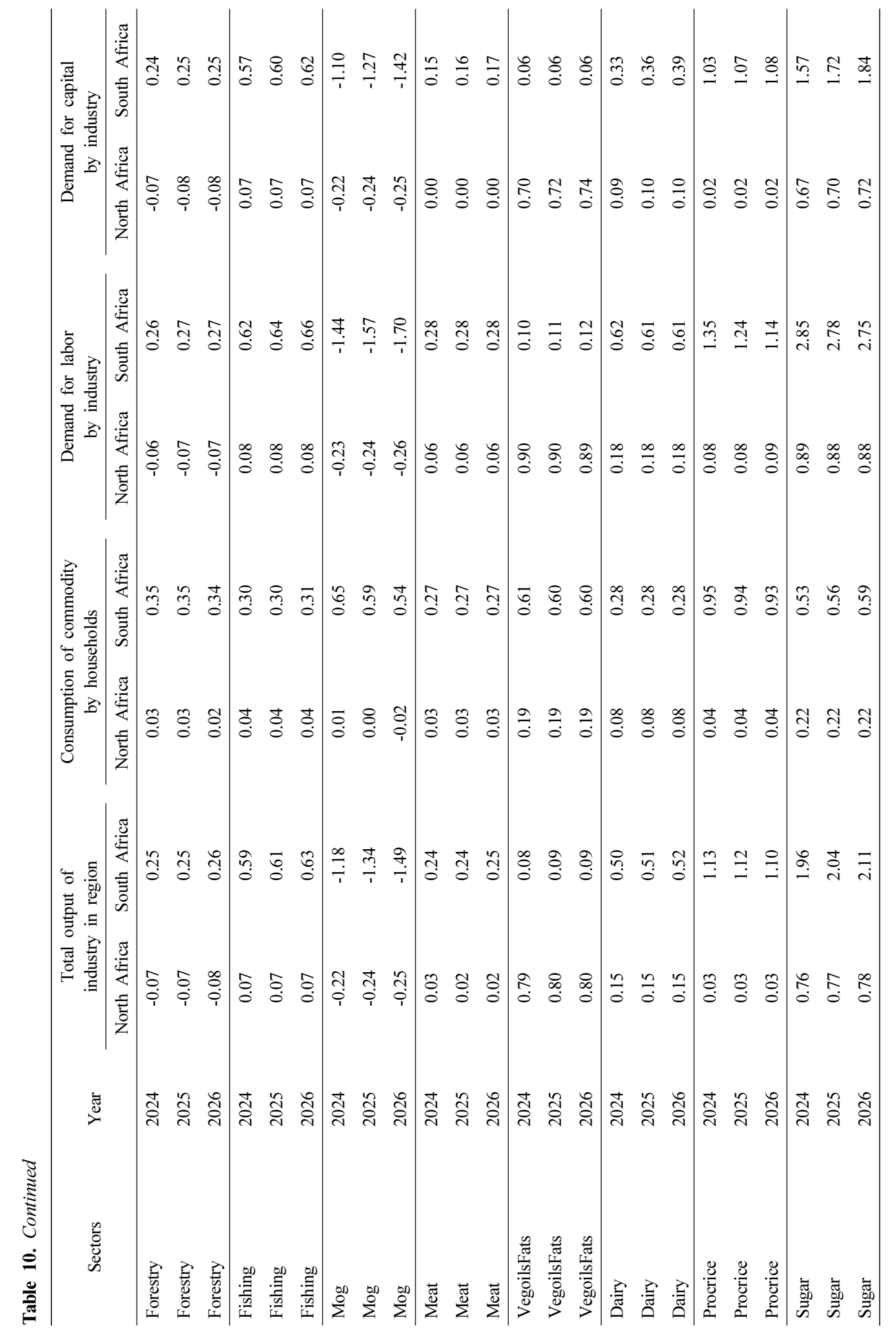




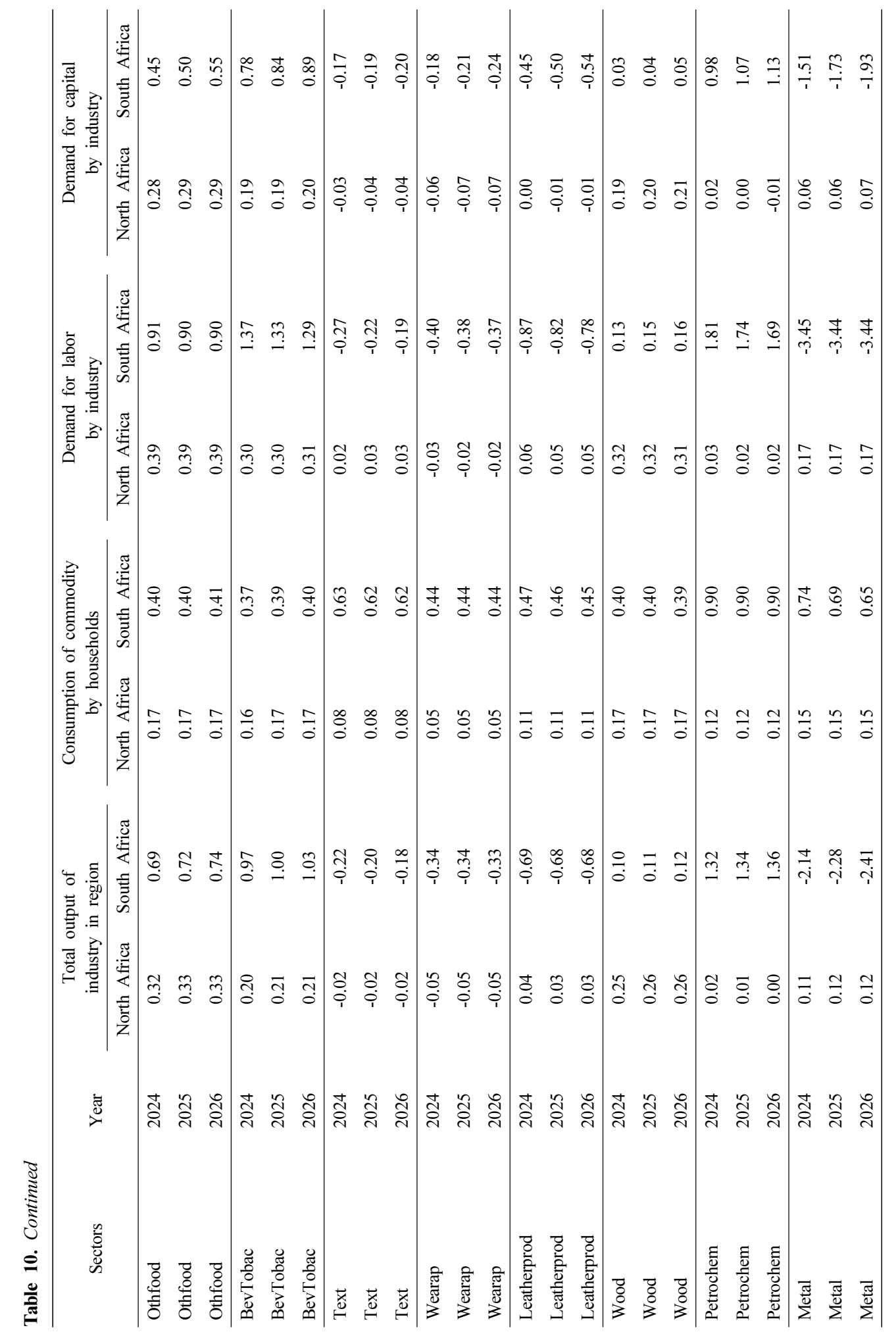




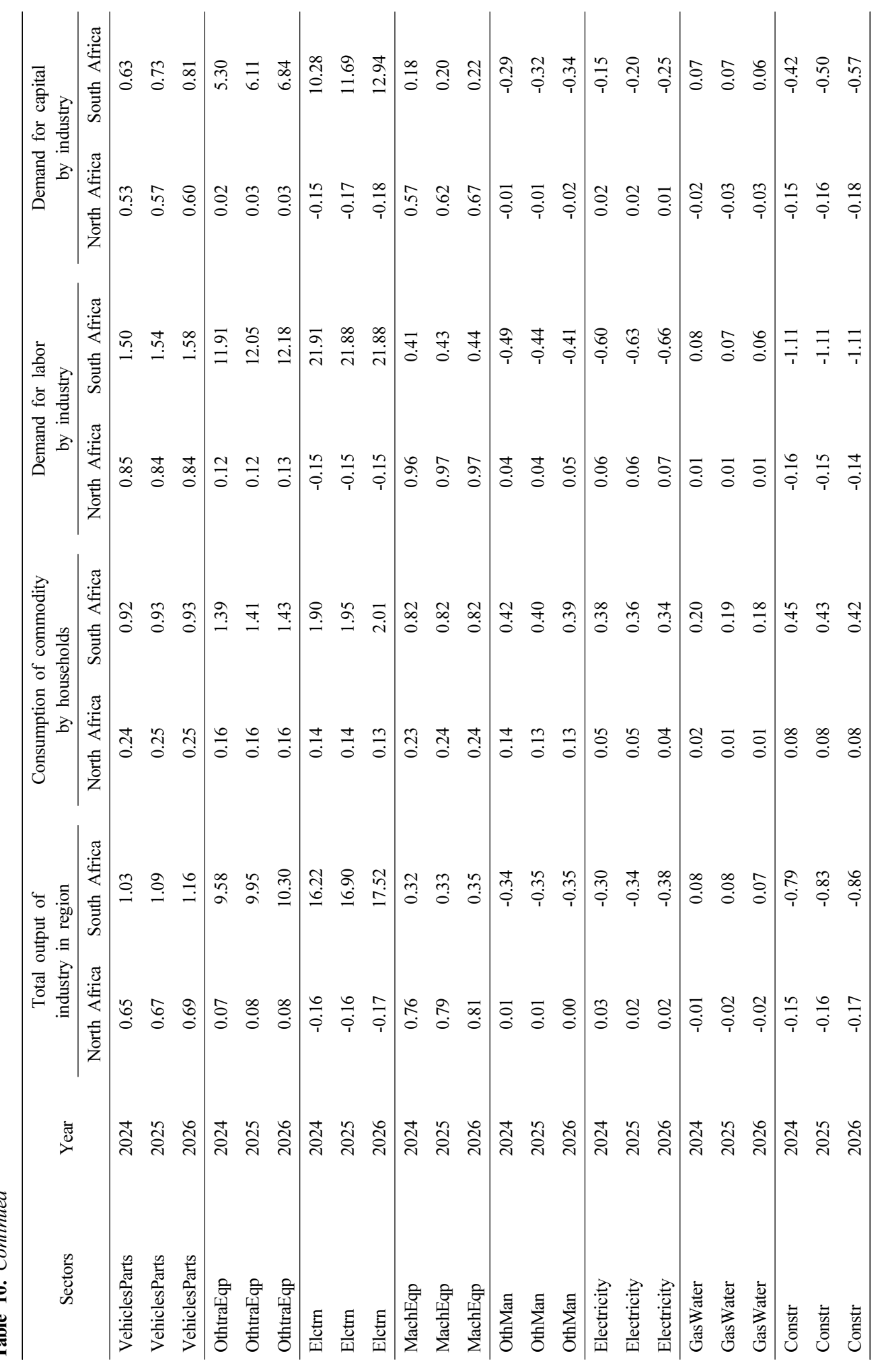




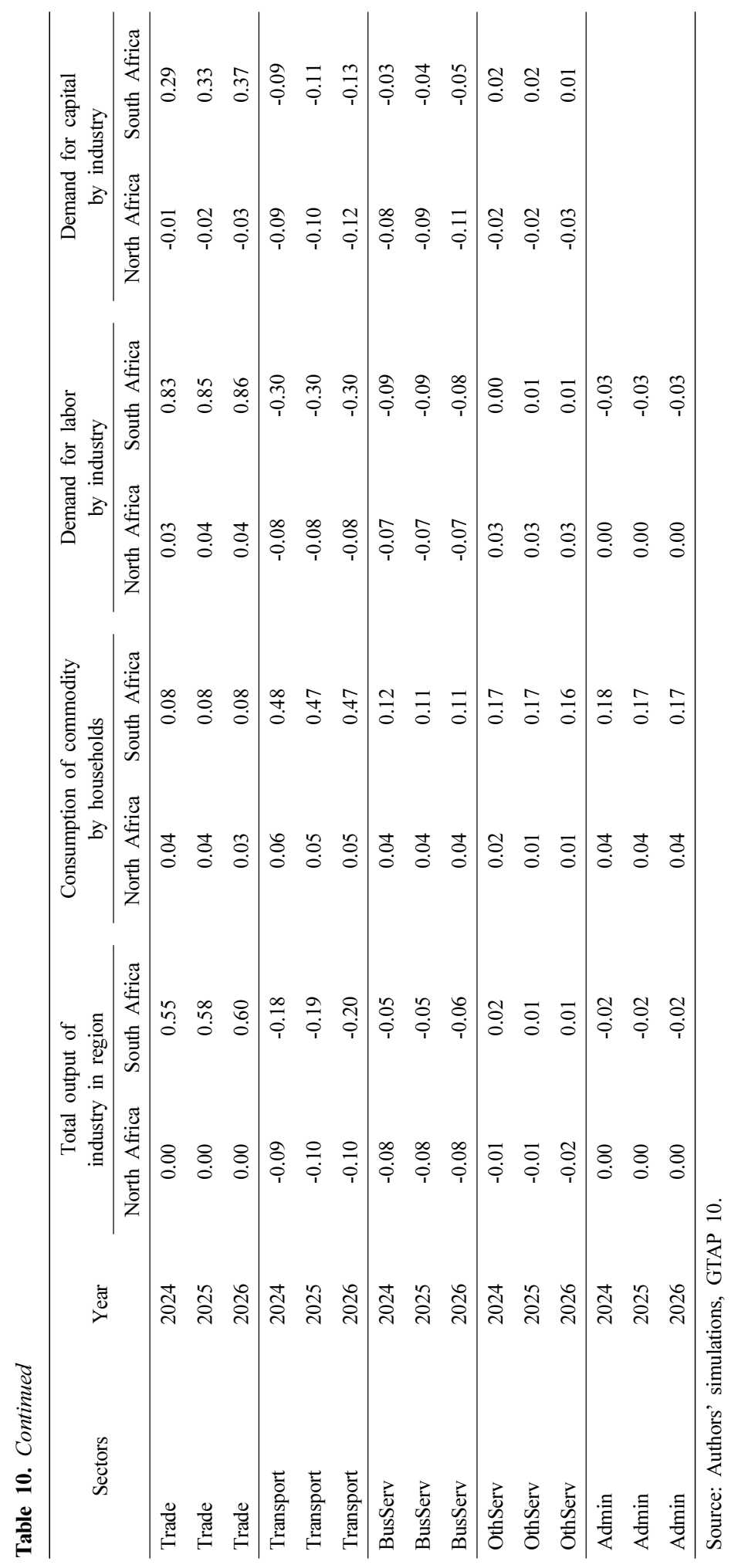


Table 11. Sectors Description

\begin{tabular}{llllll}
\hline 1 & Grains & cereal grains & 18 & Wood & Wood and paper products \\
\hline 2 & VegFruitNuts & Vegetables, fruit, nuts ( & 19 & Petrochem & Petroleum and Chemical products \\
\hline 3 & Crops & crops & 20 & Metal & Metal products \\
\hline 4 & Animals & Animal products & 21 & VehiclesParts & Motor vehicles and parts \\
\hline 5 & Forestry & Forestry & 22 & OthtraEqp & Other transport equipment \\
\hline 6 & Fishing & Fishing & 23 & Elctrn & Electronic, computer, optical products \\
\hline 7 & Mog & Mineral products, gas and oil & 24 & MachEqp & Machinery and equipment \\
\hline 8 & Meat & Meat products & 25 & OthMan & Other manufactures \\
\hline 9 & VegoilsFats & Vegetable oils and fats & 26 & Electricity & Electricity \\
\hline 10 & Dairy & Dairy products & 27 & GasWater & Gas and Water \\
\hline 11 & Procrice & Processed rice & 28 & Constr & Construction \\
\hline 12 & Sugar & Sugar & 29 & Trade & Trade services \\
\hline 13 & Othfood & Other food products & 30 & Transport & Transport \\
\hline 14 & BevTobac & Beverages and tobacco products & 31 & BusServ & Business services \\
\hline 15 & Text & Textiles & 32 & OthServ & Other business services \\
\hline 16 & Wearap & Wearing apparel & 33 & Admin & Public administration \\
\hline 17 & Leatherprod & Leather products & & & \\
\hline
\end{tabular}

Source: Authors, GTAP 10 